\title{
AMPHIBIAN AND REPTILE INVENTORY AND MONITORING Grand Teton and Yellowstone National Parks, 2001
}

\author{
DEBRA PATLA $\uparrow$ HERPETOLOGY LABORATORY \\ IDAHO STATE UNIVERSITY $\uparrow$ POCATELLO
}

\section{$\downarrow \quad$ INTRODUCTION}

This is a report of field work conducted in Yellowstone (YELL) and Grand Teton (GRTE) national parks, including the J.D. Rockefeller Memorial Parkway (JODR), in the summer of 2001. This project was supported by the National Park Service Inventory and Monitoring Program and the USGS Amphibian Research and Monitoring Initiative.

\section{I) S ystematic Amphibian SURVEys}

The main objective of field work in 2001was survey of potential amphibian breeding habitat in randomly-chosen watershed units, a task referred to as systematic surveys in our Greater Yellowstone (GRYE) study plan (Patla and Peterson 2001). This survey project was designed and initiated in 2000 under the USGS Amphibian Research and Monitoring Initiative (ARMI) (Patla 2001). In 2001, it was funded jointly by the NPS Inventory and Monitoring Program and USGSARMI.We plan to continue in 2002, depending on the level of funding available.

Within the selected watershed units we identified and recorded the location of active breeding sites as well as the presence of nonbreeding amphibians and reptile species. The surveys serve to document species presence, distribution, and the abundance of breeding sites across the parks, including areas that have not been previously sampled or have been under- sampled due to remoteness. Results will provide a baseline for monitoring amphibian population trends as indicated by the net gain or loss of breeding populations.

All amphibian species in the Greater Yellowstone Ecosystem (GYE) are pondbreeding species, dependent on shallow, quiet water for egg deposition and larval development (Koch and Peterson 1995). Careful searches of these habitats during an appropriate time frame are thus likely to reveal the presence of amphibians if they occur in an area. (Note: protocols for estimating detectability have been developed by ARMI and we hope to implement them in 2002). Some reptiles of the GYE also frequent wetlands: the Wandering Garter Snake (Thamnophis elegans vagrans) and the Valley Garter Snake (Thamnophis sirtalis fitchi). The amphibian surveys thus also serve to document the presence of these species, or other reptile species encountered en route to survey areas.

\section{$\downarrow \quad$ METHODS}

Amphibian surveys were conducted within watershed units as defined by 7th level hydrological units 1 (HU). Boundaries of the 7th level HU were provided by the YELL GIS department (Ann Rodman and Shannon Savage), with initial GIS work for GRTE provided by the GRTE GIS specialist (Dave Hammond). To achieve geographical distribution across the 10,000 square $\mathrm{km}$ area of the two national parks, 
we randomly selected 7 th level $\mathrm{HU}$ from every third square within a $10 \times 10 \mathrm{~km}$ grid placed over YELL and a $5 \times 5 \mathrm{~km}$ grid placed over GRTE. Within the selected units, we identified potential amphibian breeding habitat (ponds, lakes, and wetlands) using topographic and National Wetland Inventory (NWI) maps. Field crews were instructed to visit pre-identified potential habitat areas and to conduct surveys at all sites with potential habitat for pond-breeding amphibians (e.g., ponds, pools in moist or wet meadows, beaver impoundments, stream oxbows and backwaters). Surveys of all potential habitat were conducted where possible; sub-sampling was used in large blocks of habitat such as extensive wet meadows or areas dotted by wetlands with apparently similar features. In some watershed units, surveys were concentrated in the portion of the area where wetlands were clustered. Field crews were instructed not to visit distant, isolated wetlands at the far ends of watershed units lacking trails, such as in the Pleasant Valley-Lost Lake and Nez Perce units, due to time and safety constraints. Surveys followed standard amphibian visual encounter methodology (Thoms et al. 1997).

Survey work was conducted mostly by 2 two-person field crews (field technicians Jill Bergstrom, Matt Chatfield, and Josh Jones, and supervisor Deb Patla), working from the end of May until early August. In addition, a field herpetologist (Char Corkran) worked as a volunteer for the project, conducting backcountry surveys for approximately 3 weeks mid-July to early August, assisted by Meredith and Tory Taylor (who also provided horsepacking services) and Dave Corkran.

Data collected in the field included location (recorded with a GPS), time spent searching, species observed (specifying life stages and numbers of each), weather, habitat descriptors, water temperature, $\mathrm{pH}$ and conductivity. Sites were also documented with drawings and photos, and species were documented with photographs of the various life stages. We entered the data into a Microsoft Access database, based on the NPS template for an integrated natural resource database, prepared by GRYE Biological Inventory Coordinator Lane Cameron. The database houses the survey data in a set of related tables, including Locations, Events (date and time), Survey Data, and Amphibian Observations. Incidental observations of amphibians and reptiles and amphibian monitoring data were also entered in this database.

Digital photographs of sites visited and voucher photos of amphibians are stored on a CD. The Survey Data and Amphibian Observation tables in the database provide the photo identification number linking photos to sites.

\section{$\downarrow \quad$ RESULTS AND DisCUSSION}

In the summer of 2001, surveys were conducted in 15 watershed units, 7 in GRTE/JODR and 8 in YELL, distributed across the parks (Table 1 and Figure 1). Results per species and per watershed unit are presented in Table 1. A total of 342 pre-identified potential amphibian breeding sites was visited; 222 of these sites $(65 \%)$ appeared to be suitable for amphibian breeding based on the presence of pooled water. Of these 222 sites, $146(66 \%)$ were occupied by one or more species of amphibians, and $92(41 \%)$ were active breeding sites for one or more amphibian species.

The largest number of breeding sites was found for Boreal Chorus Frogs, followed by Columbia Spotted Frogs, Tiger Salamanders, and Boreal Toads (Table 1 and Figure 2). (The Bullfrog is an introduced species which is known to occur at only one area in the GYE.) The same pattern holds true for both GRTE/JODR and YELL (Figure 2). Table 1 also shows the number of sites at which adults or juveniles of the species were observed but without indication of breeding. Combining breeding and non-breeding sites, spotted frogs occurred at the largest number of sites. This species frequents aquatic areas after breeding more consistently than the other amphibians and is thus more likely to be encountered in this type of survey.

The percent of pre-identified potential breeding sites found to be active breeding sites, per species, is described in Table 2. For example, $19.5 \%(\mathrm{~N}=30)$ of the 154 potential sites visited in YELL hosted breeding Columbia Spotted Frogs. These numbers are influenced by the nature of habitat in the selected watershed units, e.g., the numerous ponds in burned lodgepole pine forests of the Solfatara Plateau (Grebe Lake unit) supported large numbers of Boreal Chorus Frogs but few other amphibian species. Data on precise breeding site locations from the 2001 surveys, combined with previous years data from 
surveys and monitoring, can be used to determine which NWI sites (or wetlands identified by other systems) are most likely to host breeding by the various species (as in Munger et al. 1998). This will assist future survey efforts and support construction of predictive models.

Although we focus on finding breeding sites, which provide a means to monitor population trends, the surveys also serve to document the presence of amphibian species per watershed unit. If declines of amphibians occur in the GYE, data on species presence per unit could also be of use in interpreting causative factors. Table 3 summarizes species presence, combining the observation data and breeding site data records. Two units (upper Duck Creek and Nez Perce Creek), both on the west side of YELL, had all four expected species.

To depict the distribution of sites surveyed and active breeding sites, maps are provided in Figures 3-16. These maps show 14 watershed units (on 1:24,000 topographic maps extracted from All Topo Maps:Wyoming, iGage) with symbols to indicate locations of surveys (red dots) and locations of breeding sites per species (red dots are covered by species symbols). The Gros Ventre River unit, where stream-side surveys took place, is not illustrated because of the discrepancy between the map and the actual location of the river relative to the GPS data (see Table 1 for results of surveys in this unit). Figure captions provide additional information about the individual units. The database and various data layers in ArcView will allow analysis of relationships, such as cooccurrence of species, elevation ranges, and habitat associations.

Results of su rveys in 2001 were likely influenced by drought conditions. Some sites that probably host breeding populations in normal or wet years were dry and unsuitable as habitat in 2001. However, survey of several to many sites per watershed unit, including a variety of ephemeral and permanent water bodies, mitigated this problem to some extent. Two units may have been surveyed too early (Pleasant Valley in northern YELL) or too late (Chipmunk Creek in southern YELL) to detect all breeding species. When surveys are repeated in the future, data from 2001 will provide the opportunity to investigate the effects of variation among years, survey timing, weather patterns and conditions, etc. on survey results in terms of breeding site numbers and detected species presence.

\section{II) TARGETEd SPECIES SURVEYS}

Under our study plan for the NPSGRYE inventory project, targeted species and repeat historic surveys are included to document the presence of amphibian and reptile species that were known to have occurred in the network parks based historic records, are expected to occur based on habitat and regional occurrence, or which have uncertain status. Boreal Toads are of special concern because of potential declines in the GYE, devastating chytrid disease outbreaks in Colorado, and the discovery of this disease in 2000 on the National Elk Refuge in Jackson Hole. In YELL and GRTE in 2001, under our study plan, we planned to visit a subset of previously-identified Boreal Toad breeding sites ( 3 in GRTE and 5 in YELL) to determine if toads continue to breed at these sites. The Northern Leopard Frog is also of concern. This species was documented in GRTE in the 1950s, but no breeding sites are currently known.

\section{$\downarrow$ MeTHODS}

We conducted visual encounter surveys at sites where Boreal Toads have bred in recent years (e.g., since 1990) during time periods where eggs, tadpoles, or metamorphs were likely to be present (mid-May through A ugust). If the sites were not occupied, we conducted surveys in the general area to search for new or re-located sites.

In 2001, we did not conduct any searches specifically for leopard frogs. However, one of the watershed units, Polecat Creek, is in the general vicinity of the last reliable, documented observation of this species (1995).

\section{$\uparrow \quad$ RESUlts}

We visited 6 previously-identified Boreal Toad breeding areas in YELL (Table 4A, Figure 17), and 5 areas in GRTE/JODR (Table $4 \mathrm{~B}$, Figure 17) to determine if toads remained present and reproductively active in 2001. In addition, we monitored 5 of these sites, returning later in the season to see if the larvae 
successfully metamorphosed (Table $4 \mathrm{~A}$ and B). This w ork exceeded our 2001 Inventory/Survey Study Plan targets due to support from ARMI and donated time.

We found that most but not all areas remained occupied by breeding populations of Boreal Toads: 5 out of 6 in YELL, and 4 out of 5 in GRTE/JODR. As for the inactive sites, the inactive area in YELL (Alum Creek) may have required more field work to detect toads. However, in 2000 toads and tadpoles were so abundant in this area that we could not have missed them in 2001 if they remained present in similar or even greatly reduced numbers, so a decline since last year is suggested. In the Colter Bay area, the sites that were active last year and large portions of Colter Bay were surveyed for 2 $1 / 2$ days, without any detection of toads. Water levels of Jackson Lake were drastically reduced by drought and reservoir draw-downs in 2001, probably rendering the previous breeding sites unsuitable even early in summer.

Monitoring of toad breeding sites in 2001 indicates that survival of tadpoles was probably poor, based on the small numbers of metamorphs observed. In addition, metamorph size at the most productive site (South Entrance thermal stream) was smaller than is normal for GYE toadlets, ranging 8.8 to $12.2 \mathrm{~mm}$ snouturostyle length; toadlets are usually $11-18 \mathrm{~mm}$ (D. Patla, unpublished data). The small number of toad metamorphs in 2001, as well as their small size at South Entrance, were likely due to drought conditions. Available habitat was strikingly reduced at all toad breeding sites except Schwabacker Landing, where beavers have rebuilt dams and constructed a large new shallow-water environment.

Poor breeding years are not unusual for amphibian populations in the GYE, and populations are generally expected to recover with time and the return of suitable conditions. However, populations can quickly decline to extinction if, in addition to recruitment failures, adults are suffering high mortality from disease, adverse weather, or other factors. It is thus highly recommended that monitoring of known toad breeding sites continue and increase in intensity if possible, given the rapid disappearance of toads in other parts of the country, such as Colorado.
No leopard frogs were detected during surveys of the Polecat Creek watershed unit or visits to the Boreal Toad breeding site in the area. In 2002 we will conduct targeted surveys for this species.

Reptiles

The bulk of reptile inventory work is planned for 2002 and 2003 (Patla and Peterson 2001). In 2001, we documented the occurrence of Wandering Garter Snakes encountered during amphibian surveys. In addition, incidental observations of reptiles were made during the course of field work and field trips in the GRYE. Ryan Baum conducted searches for snakes in known and suspected snake den areas, and documented two active rattlesnake dens. These data are included in the Reptile Observations tables in the database submitted with this report. Figure 18 shows the general locations of the observations.

\section{Amphibian and Reptile Inventory Results} Amphibian Species Detected in 2001

\section{GRTE}

Blotched Tiger Salamander (Ambystoma tigrinum melanostictum)

Boreal Toad (Bufo boreas boreas)

Boreal Chorus Frog (Pseudacris maculata)

Columbia Spotted Frog (Rana luteiventris)

Bullfrog (Rana catesbeiana)

Northern Leopard Frog (Rana pipiens), which was present historically and documented with a photo in 1995 near Flagg Ranch, was not detected.

\section{JODR}

Blotched Tiger Salamander (Ambystoma tigrinum melanostictum)

Boreal Toad (Bufo boreas boreas)

Boreal Chorus Frog (Pseudacris maculata)

Columbia Spotted Frog (Rana luteiventris)

YELL

Blotched Tiger Salamander (Ambystoma tigrinum melanostictum)

Boreal Toad (Bufo boreas boreas)

Boreal Chorus Frog (Pseudacris maculata)

Columbia Spotted Frog (Rana luteiventris) 
Reptile Species detected in 2001 (Figure 18)

GRTE

Wandering Garter Snake (Thamnophis elegans vagrans)

JODR

Wandering Garter Snake (Thamnophis elegans vagrans)

YELL

Northern Sagebrush Lizard (Sceloporus

graciosus graciosus)

Wandering Garter Snake (Thamnophis elegans vagrans)

Prairie Rattlesnake (Crotalis viridis viridis)

\section{III) Lodge CReEk Sentinel Site}

Under ARMI, a small number of selected areas in a region are designated as "sentinel sites", where intensive population studies are conducted. Types of studies that are conducted at sentinel sites include investigation of demographic and life history characteristics of key species, the relation of environmental change to changes in demographic and life history characteristics over time, cause-effect of population changes, and protocol and technique development (USGS-ARMI 2001). Commonly, sentinel sites are areas where amphibian population data have been collected annually over the past several years.

The Lodge Creek (Figure 19) area serves as a sentinel site in the GYE-ARMI project. Work in 2000 and 2001 was funded by ARMI and supplemented by volunteer time. The Columbia Spotted Frog population of the Lodge Creek area was studied intensively during the years 1953-55 (Turner 1960), and again 1993-95 (Patla 1997; Patla and Peterson 1999), with continued monitoring since 1995. Research in the mid 90s revealed that the population had declined sharply (about 70-80\%) since the 1950s. Continued monitoring of the site allows study of life history, demographic characteristics, and habitat use patterns over time, and observation of responses of the population to annually fluctuating weather and human activities (e.g., fuel hazard reduction and residential development in the area). In addition, it allows us to work with resource managers to apply mitigation measures, and to apply and test the technique of photo-identification as a means of population size estimation. Previous and current research contributes to an understanding of how human-caused habitat modifications may contribute to population decline. A publication on previous research at Lodge Creek is in progress.

\section{$\downarrow$ METHODS}

In 2001, we conducted breeding-site monitoring and capture/recapture work (using photo identification) within occupied habitat (breeding, foraging, and wintering sites). The area was visited on 14 occasions between May 15 and Sept. 14, with some occasions consisting of two or more days of field work. In the main study area, 96 frogs were captured and photographed in the initial capture period (July 15-16); 92 frogs in the recapture period (Aug. 21-23). Additional capture-photography was conducted at the mouth of Lodge Creek at Yellowstone Lake.

\section{$\uparrow \quad$ RESUlts AND Discussion}

Results for the main study area are presented in Table 5. Population estimates are pending, and will be based on analysis of the digital photos of individual frogs to ascertain recapture rates. In 2001, we found that $25 \%$ of the population was in the juvenile life stage, compared to $52 \%$ in 2000 . This reduction probably reflects recruitment failure in 2000, which was a drought year. In 2001, the drought continued and very few tadpoles survived to metamorphosis in the main study area; we thus expect to see continued decline of the juvenile component of the population in 2002. We also predict that winter mortality may be high this winter (2001-2002) due to low water levels in the springs and streams where the frogs hibernate.

The reason for disproportionate numbers of males versus females during both years, and especially in the second capture period of 2001, is unknown. This will be investigated further by comparison to data collected in the mid-90s. One hypothesis is that female frogs disperse more widely during the summer and so are less likely to be caught in the currently known habitat areas during the two discrete capture periods. Another is that mature 
females, which unlike males do not breed every year, tend to disperse out of the main study area during drought years.

Habitat use patterns (based on frog distribution as revealed by the capture surveys) indicated that frogs continue to avoid the portion of Lodge Creek within the horse pasture, where stream banks and stream-side vegetation have been apparently affected by grazing. This stream section is also directly below the outflow from the Lodge Creek chlorination/pumping station. Frog use of the forested area most heavily disturbed by fuel hazard reduction (near the horse corral adjacent to the barn) was also scant, although one frog was found under reintroduced woody debris. Improvements of the fence around the breeding pool by Lake district resource management staff appeared to help improve habitat quality and extend water retention. Spotted frog breeding attempts at the wetland adjacent to FHA housing (which we think is a relatively new breeding site) failed when the wetlands dried up in early August. However, spotted frogs did breed successfully in the lagoon at the mouth of Lodge Creek, and some of the recruits were found dispersing upstream in the fall; possibly they will add to the frog population in the main study area. Near the lagoon, we located an over-wintering site in a small spring. This site appears to be used only by young-of-the-year, probably because the opening into the underground spring is so small. Froglets migrate from the lagoon along Lodge Creek and up a small drainage to reach this area. Discovery of this over-wintering site is significant because very few spotted frog hibernacula have been identified in the GYE.

\section{Amphibian Disease and Mortality}

Dead and diseased amphibians are of interest because of the role disease may be playing in amphibian population declines (Daszak et al. 1999). In 2001, we collected dead amphibians encountered during surveys.

Specimens were sent to Dr. D. Earl Green at the USGS National Wildlife Heath Center, Madison, WI, on August 27, 2001.

Specimens were preserved in $75 \%$ ethanol or frozen. Shipping and examination costs were covered by ARMI. Results are pending completion of pathology reports.

\section{REFERENCES CITED}

Daszak P., Berger, L., Cunningham, A. A., Hyatt, A. D., Green, D. E. and Speare, R. 1999. Emerging infectious diseases and amphibian population declines. Emerging Infectious Diseases Journal [serial online] 1999 Nov-Dec 5(6). Available from: URL: http://www.cdc.gov/ncidod/EID/vol5no 6/daszak.htm.

Koch, Edward D, and Charles R. Peterson. 1995. Amphibians and Reptiles of Yellowstone and Grand Teton National Parks. Salt Lake City: University of Utah Press.

Munger, J.C. M. Gerber, K. Madrid, M. Carroll, W. Petersen, and L. Heberger. 1998. US. National Wetland Inventory classifications as predictors of the occurrence of Columbia spotted frogs (Rana luteiventris) and Pacific treefrogs (Hyla regilla). Conservation Biology 12 (2):320-330.

Patla, D.A. 1997. Changes in a population of spotted frogs in Yellowstone National Park between 1953 and 1995: the effects of habitat modification. M.S. Thesis, Idaho State University.

Patla, D.A. 2001. Status and trends of amphibian populations in the Greater Yellowstone Ecosystem: progress report, 2001, submitted to Rocky Mountain Regional Coordinator, USGS Amphibian Research and Monitoring Initiative.

Patla, D.A. and C.R. Peterson. 1999. Are amphibians declining in Yellowstone National Park? Yellowstone Science 7(1): 2-11.

Patla, D.A., and C.R. Peterson. 2001. Amphibian and Reptile Inventory/Survey Study

Plan, 2001, submitted to National Park Service March 6, 2001. 
Thoms, C, C. C. Corkran, and D.H. Olson. 1997. Basin amphibian survey for inventory and monitoring in lentic habitats. In Sampling Amphibians in Lentic Habitats. D.H. Olson, W.P. Leonard, and R..B. Bury, eds. Northwest Fauna 4. Society for Northwestern Vertebrate Biology, Olympia, WA.

Turner, F.B. 1960. Population structure and dynamics of the western spotted frog, Rana p. pretiosa Baird \& Girard, in Yellowstone Park, Wyoming. Ecol. Monographs 30(3):251-278.

USGS ARMI Task Force. 2001. Conceptual design and implementation guidance for the Amphibian Research and Monitoring Initiative. Draft, May 11, 2001.

\section{ACKNOWLEDGMENTS}

A sincere thank you to the many people who contributed to this project. Lane Cameron coordinates the GRYE Biological Inventory Program and provided greatly appreciated assistance with the study plan, permits, lodging, communications, and creating the database. P. Stephen Corn made this extended project possible by incorporating Greater Yellowstone in the USGS Amphibian Research and Monitoring Initiative. Chuck Peterson, who serves as principal investigator for Greater Yellowstone
Ecosystem-ARMI and the GRYE AmphibianReptile Inventory and Monitoring project, was instrumental in the design and implementation of this project. Yellowstone National Park personnel helping us with varied aspects include: Christie Hendrix, Ann Rodman, Shannon Savage, Mike Grieco, Pat Perotti, Dan Reinhart, Susan Ross, and Anita Varley. Grand Teton personnel who assisted us include: Bob Schiller, Dave Hammond, Andrew Langford, Martha Lyon, Mason Reid, and Susan Wolff. Thanks also to Hank Harlow at the U.W. National Park Service Research Center for his assistance with lodging and for sharing information on his research on Boreal Toads at the Snake River quarry. At Idaho State University, Shirley Buchli and Connie Peck provided support with supplies, equipment, and personnel matters. Merlin Hare created the maps and cover page for this report, prepared the portable document file, and provided technical and computer assistance throughout the 2001 project. This project is also particularly indebted to the excellent field crew of 2001: Jill Bergstrom, Matt Chatfield, Char and Dave Corkran, Josh Jones, and Meredith and Tory Taylor. Char volunteered her time and helped support expenses through a grant she was awarded by Sierra Club, making it possible to survey remote areas of the park. Matt and Josh were an extraordinarily capable and energetic crew; the large amphibian observation database from the summer of 2001 is largely due to their work. 


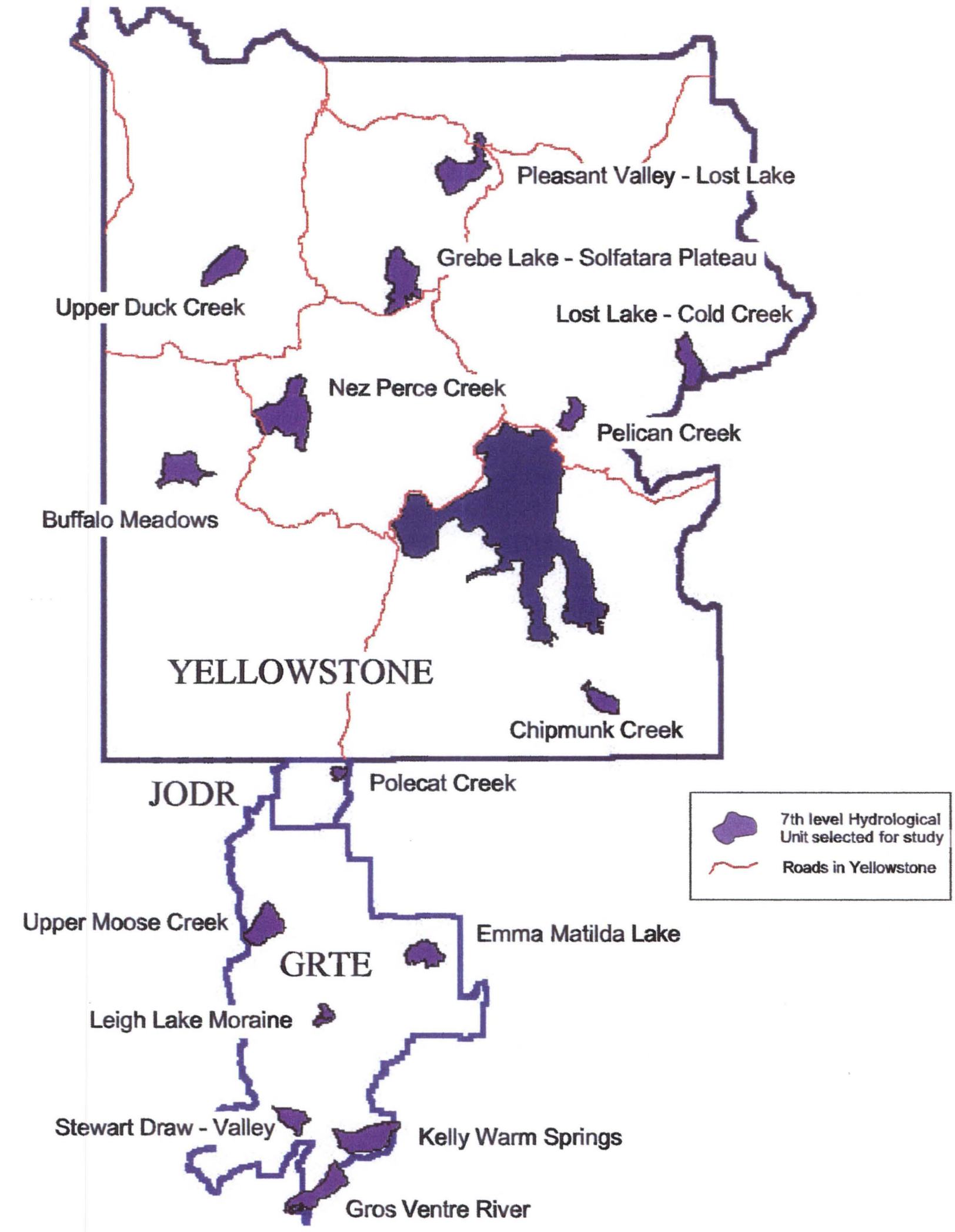

Figure 1. Watershed units surveyed in Yellowstone National Park, John D. Rockefeller Memorial Parkway, and Grand Teton National Park in 2001. 


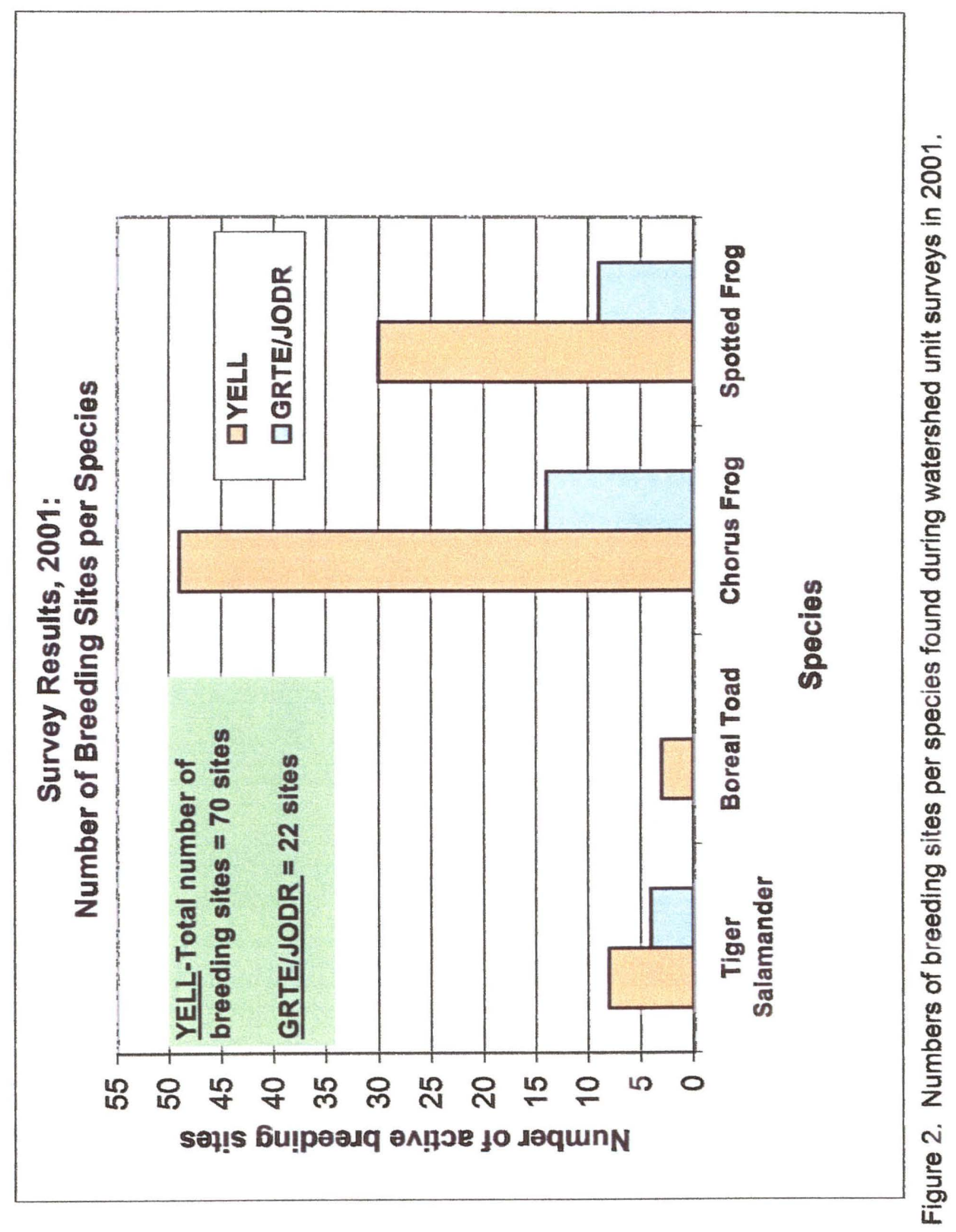




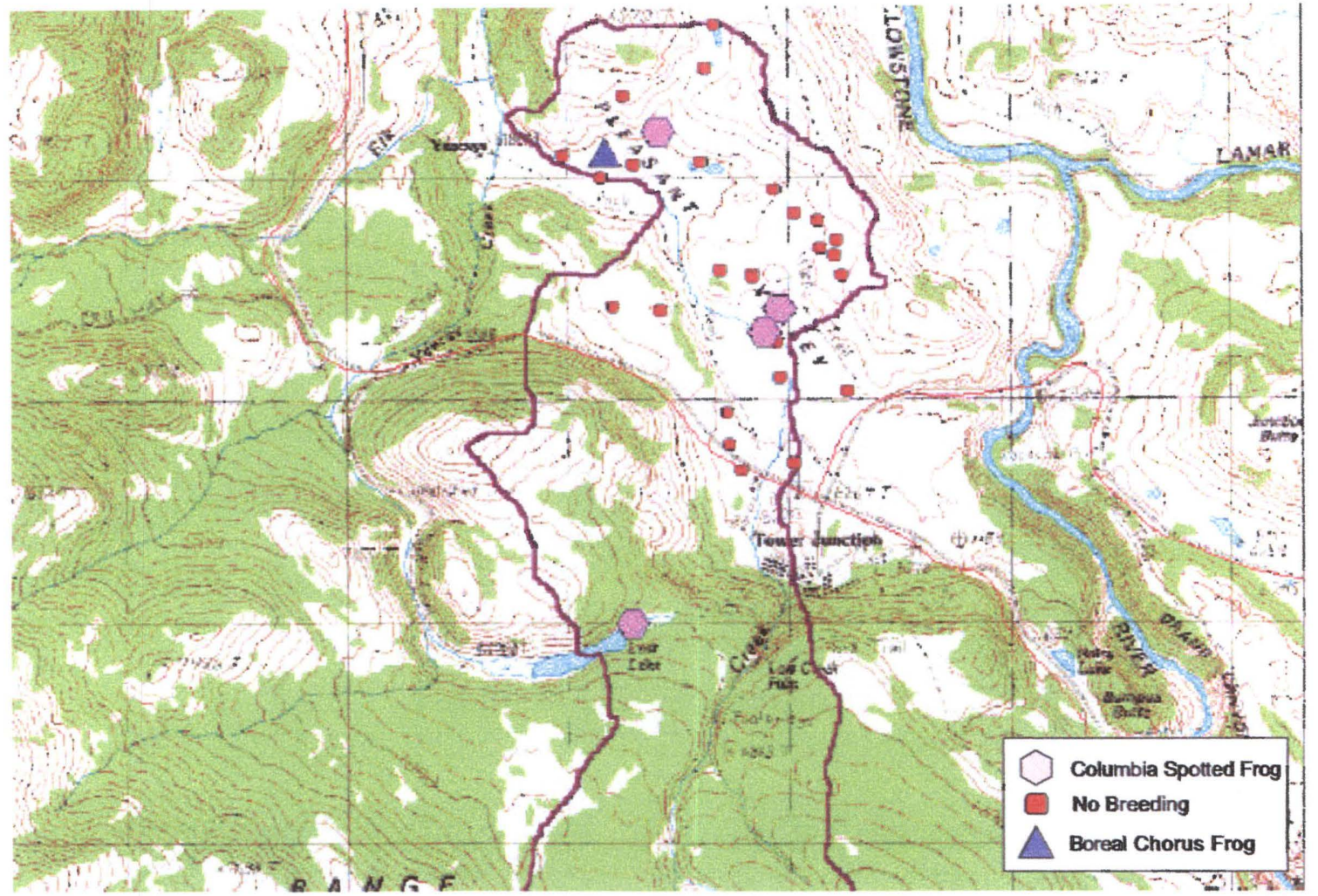

Figure 3. Pleasant Valley-Lost Lake watershed unit, YELL. Surveys were conducted only in the northern portion of the unit. Potential breeding habitat sites in the rest of the unit were remote, widely scattered, and located in a restricted travel area.

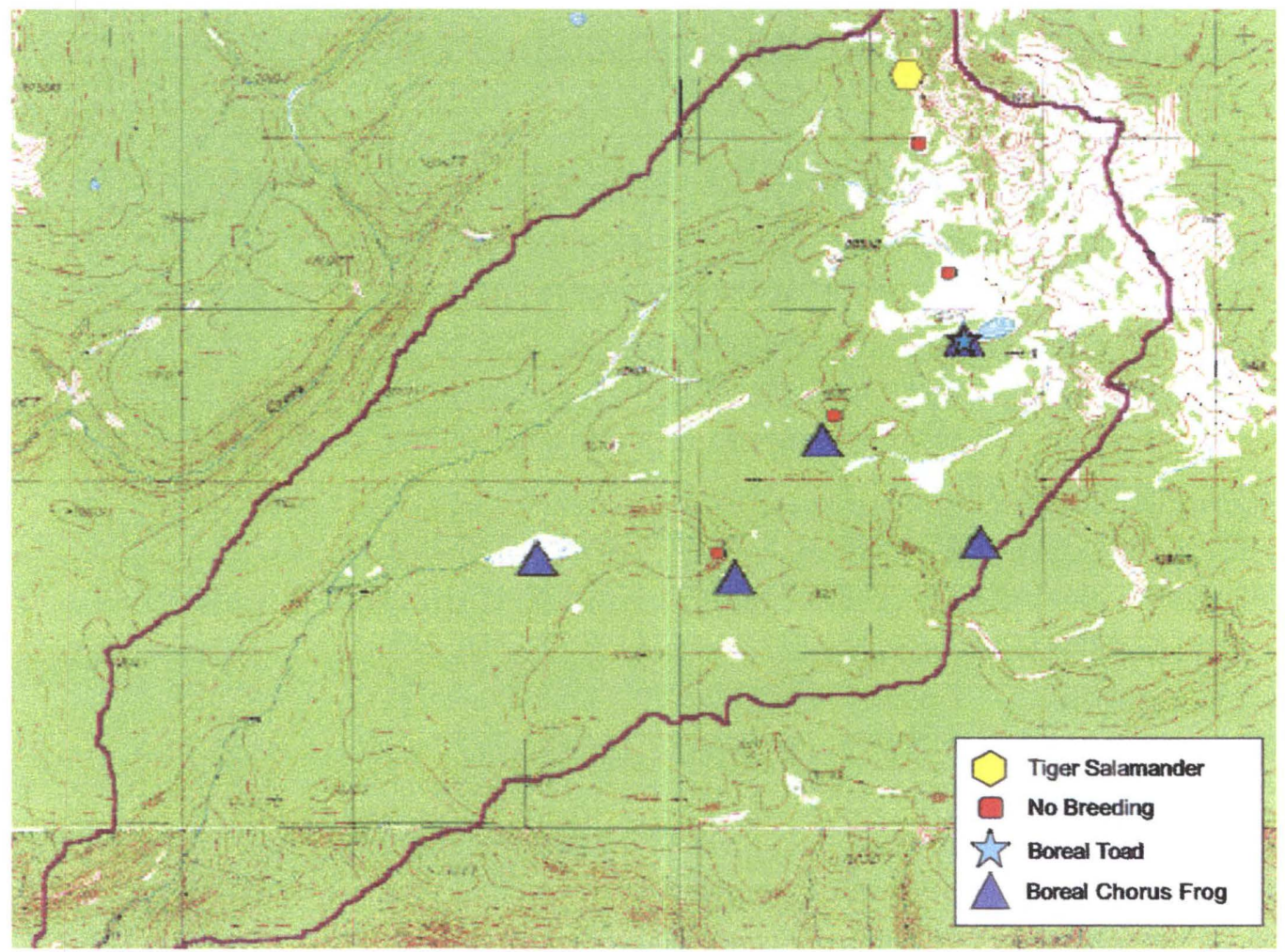

Figure 4. Upper Duck Creek watershed unit, YELL. This is one of only two units with Boreal Toad breeding. Only a few tadpoles were found, at a single site in the unit. 


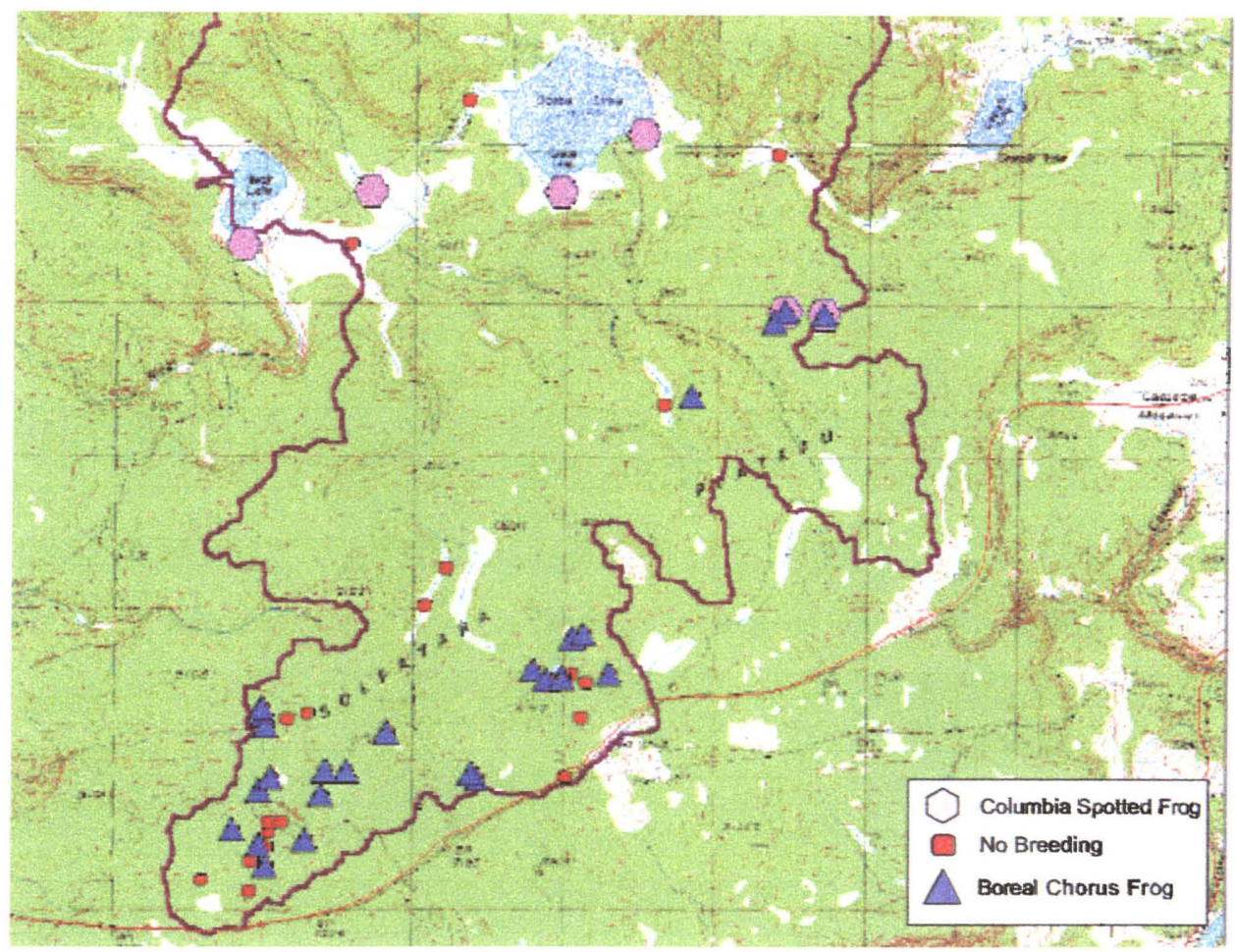

Figure 5. Grebe Lake watershed unit, YELL. Surveys were conducted in the south half of the unit; the rugged northern portion contained only two potential habitat sites. More sites were surveyed than in any other unit.

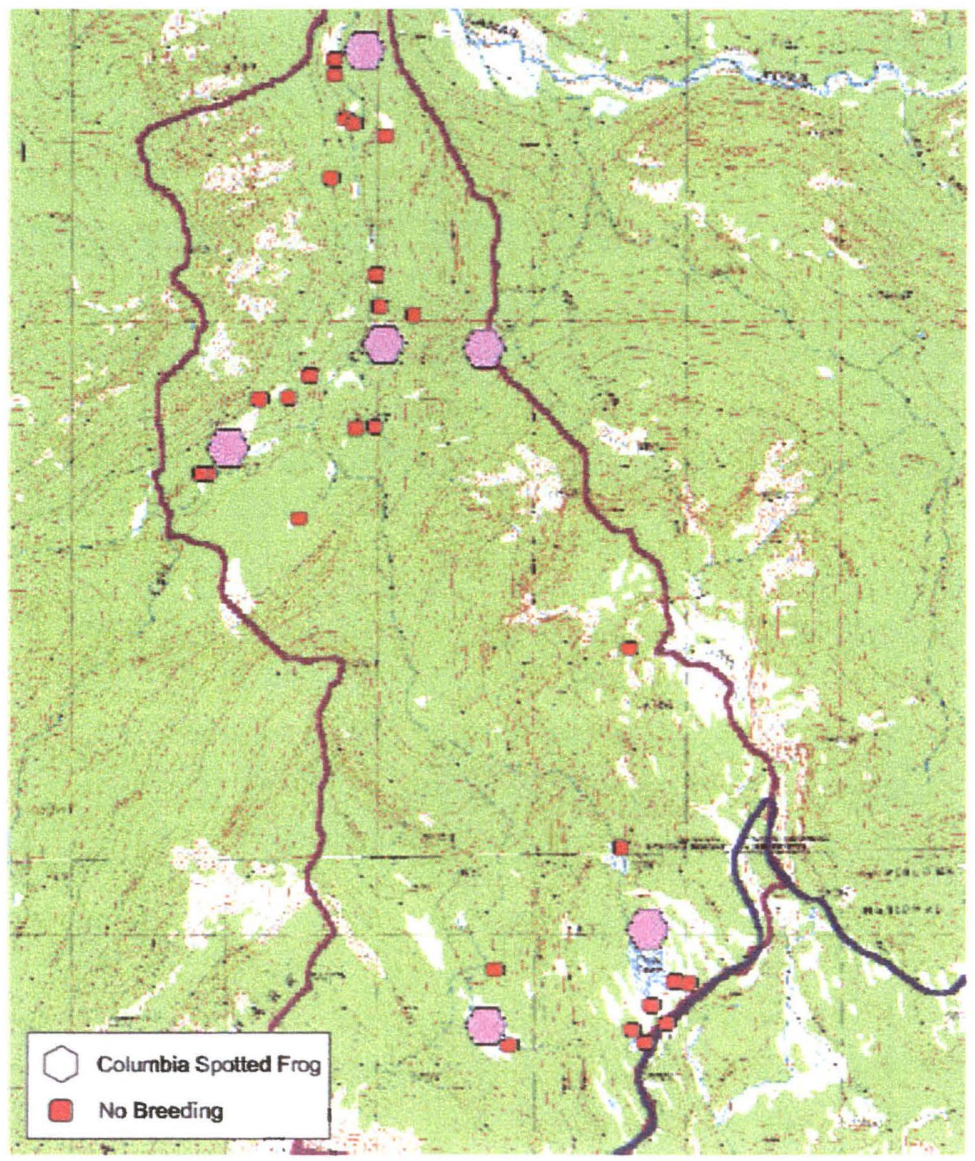

Figure 6. Frost Lake-Cold Creek watershed unit, YELL. Surveys were concentrated in the upper reaches around Frost Lake and in the lower reaches along Cold Creek. NWI sites along Cold Creek were mostly temporary and lacked surface water. 


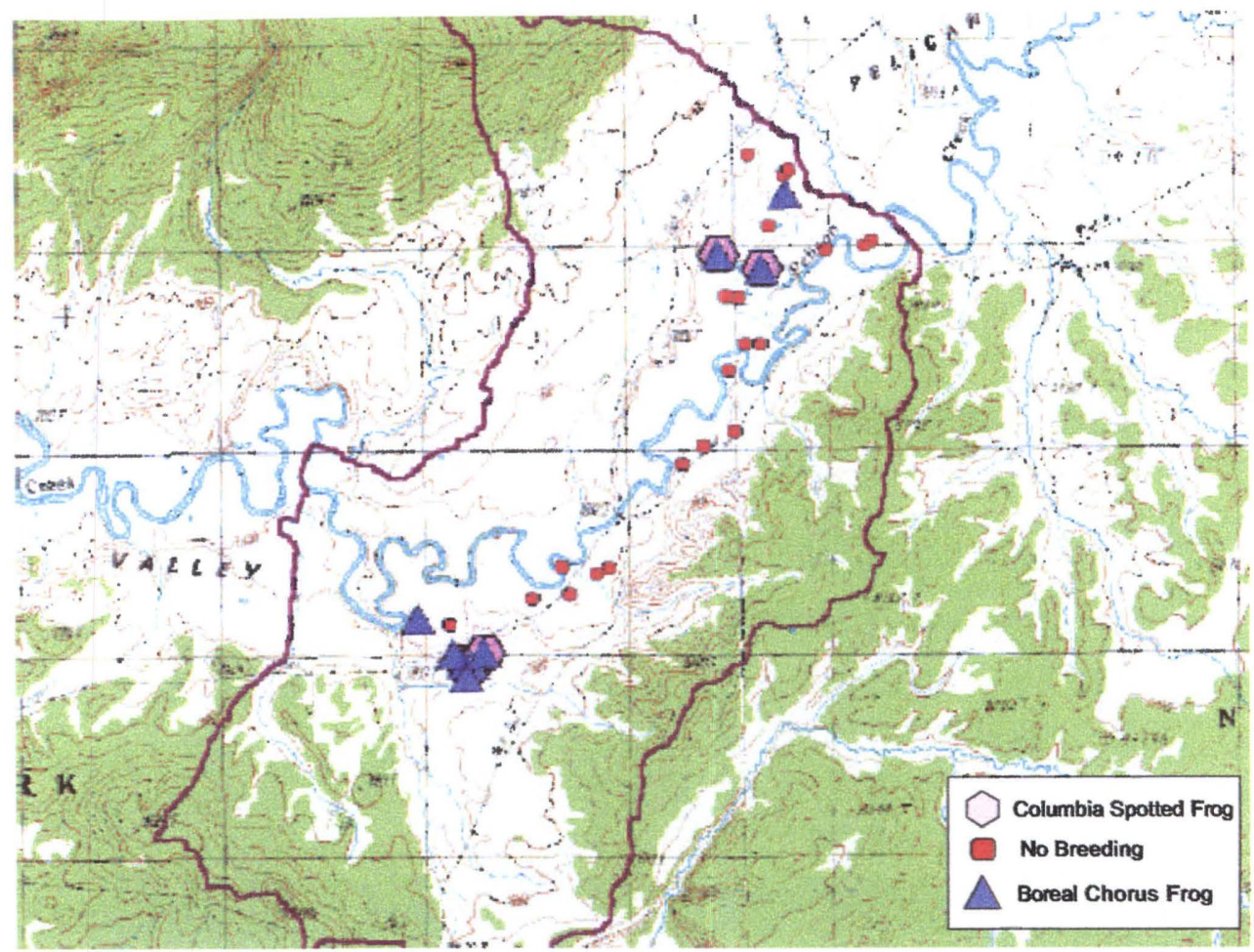

Figure 7. Pelican Creek watershed unit, YELL. This unit was under-sampled in 2001 , as dry conditions brought the survey period to an early end.

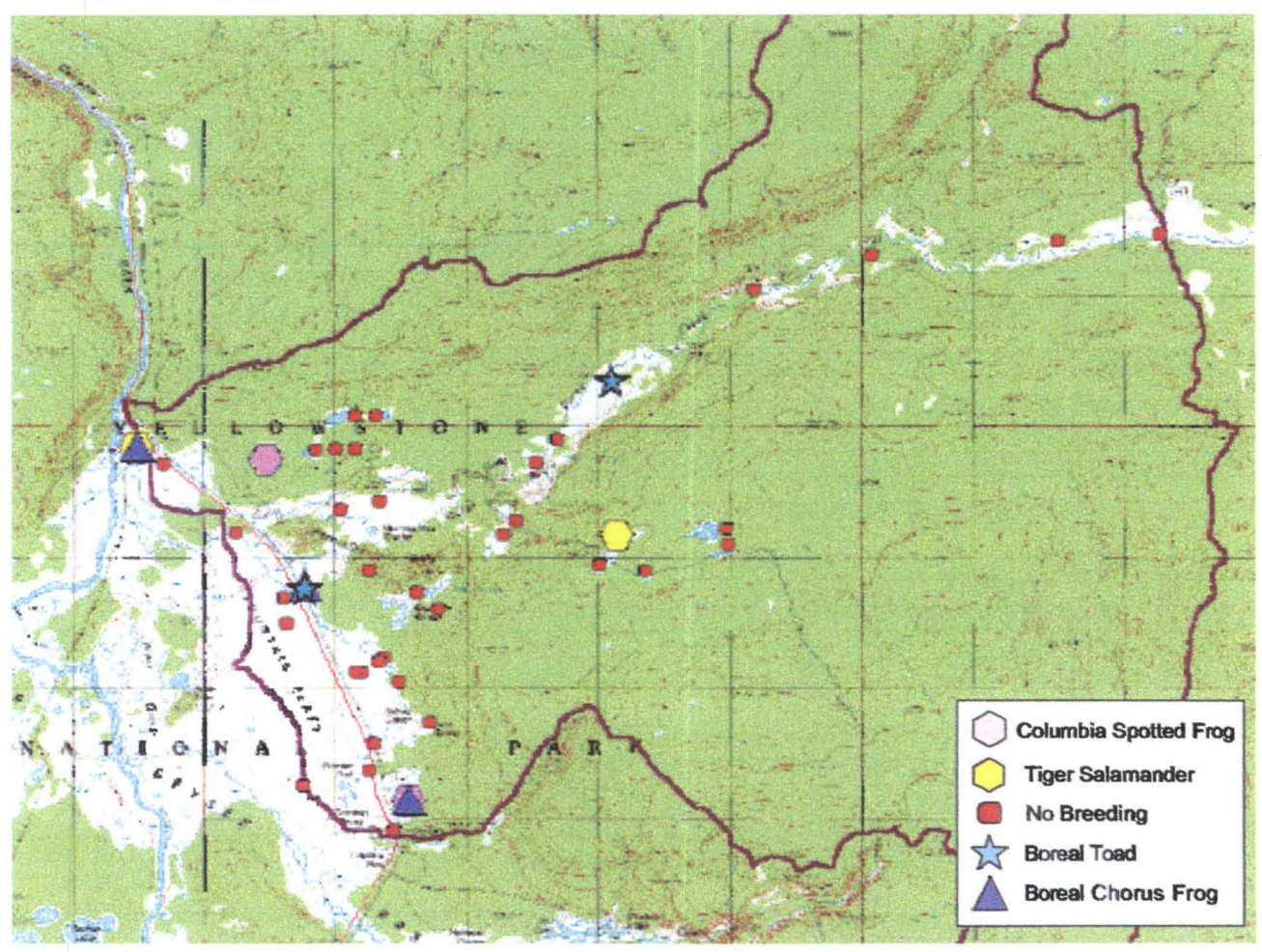

Figure 8. Nez Perce Creek watershed unit, YELL. This was one of two units in which Boreal Toad breeding sites were found. Highly scattered, small wetland units in the northeast and southeast portions of the watershed were not surveyed. 


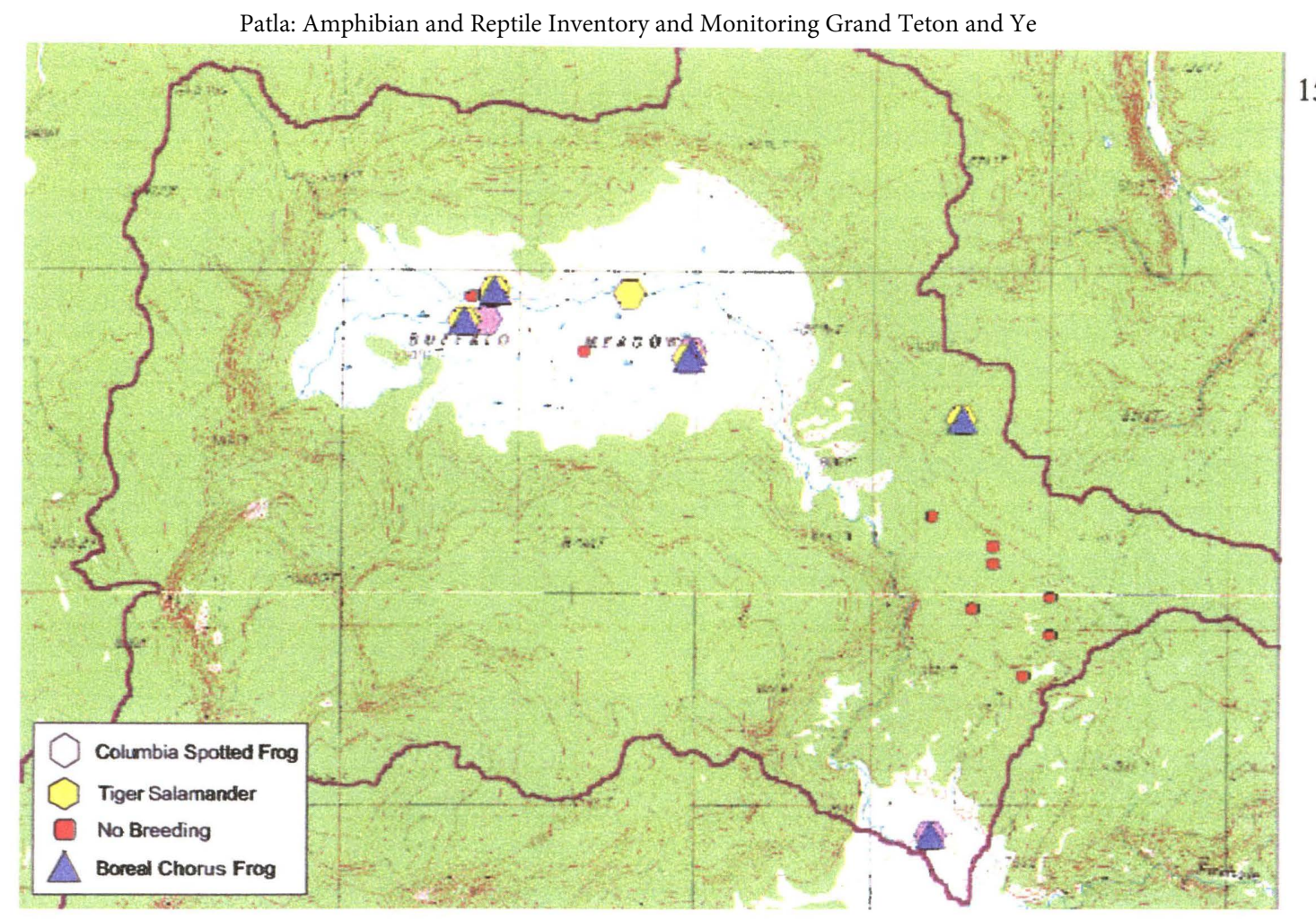

Figure 9. Buffalo Meadows watershed unit, YELL. Re-surveys of several sites visited in 2000 were conducted, and some new sites also were surveyed.

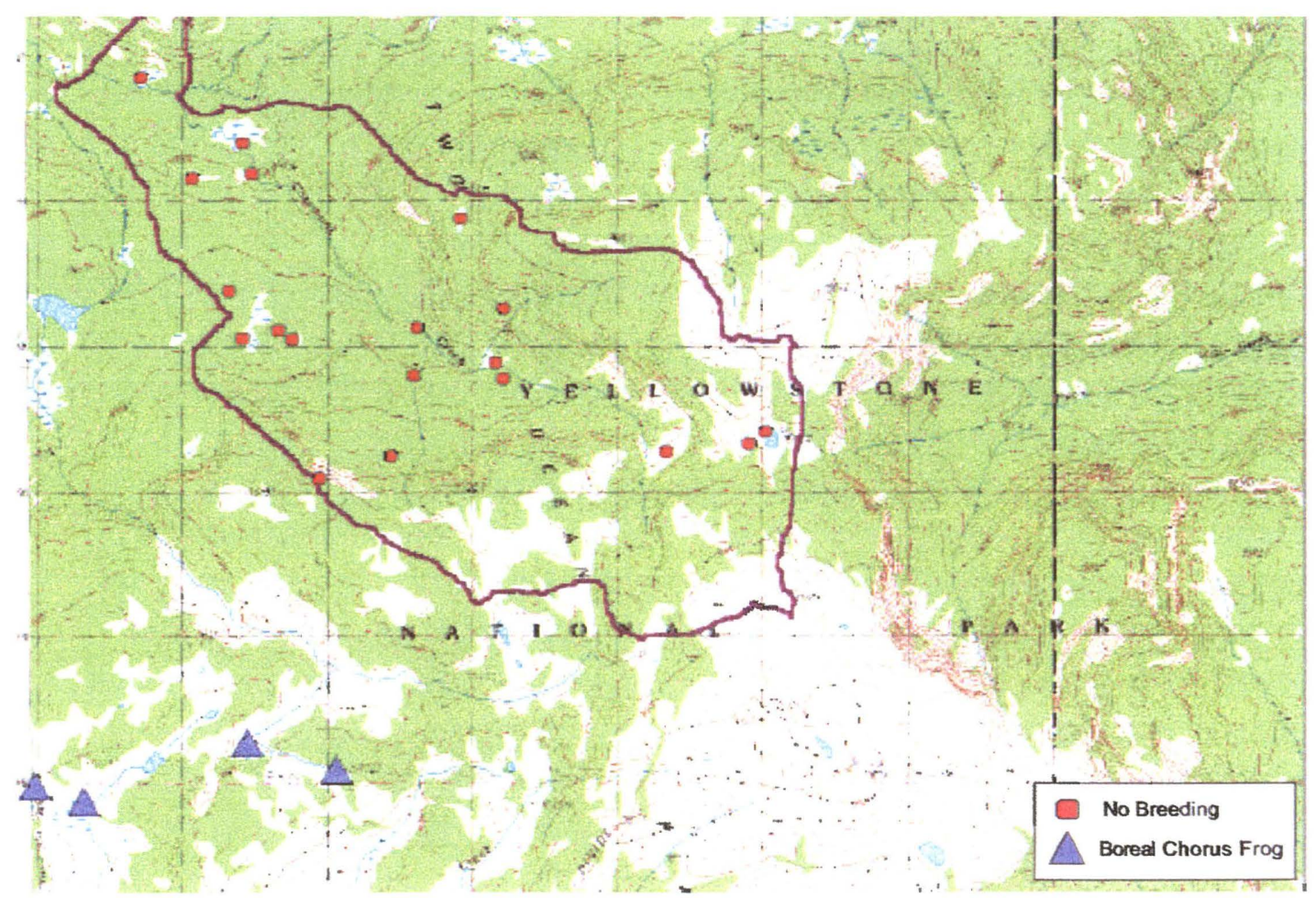

Figure 10. Chipmunk Creek watershed unit, YELL. This remote area was sampled late in the season (early August). No breeding sites were found, but Columbia Spotted Frog and Boreal Chorus Frog individuals were observed, indicating that breeding sites may be present in more favorable conditions. Some Boreal Chorus Frog breeding sites were found in drainages southwest of the unit during the same sampling period. 


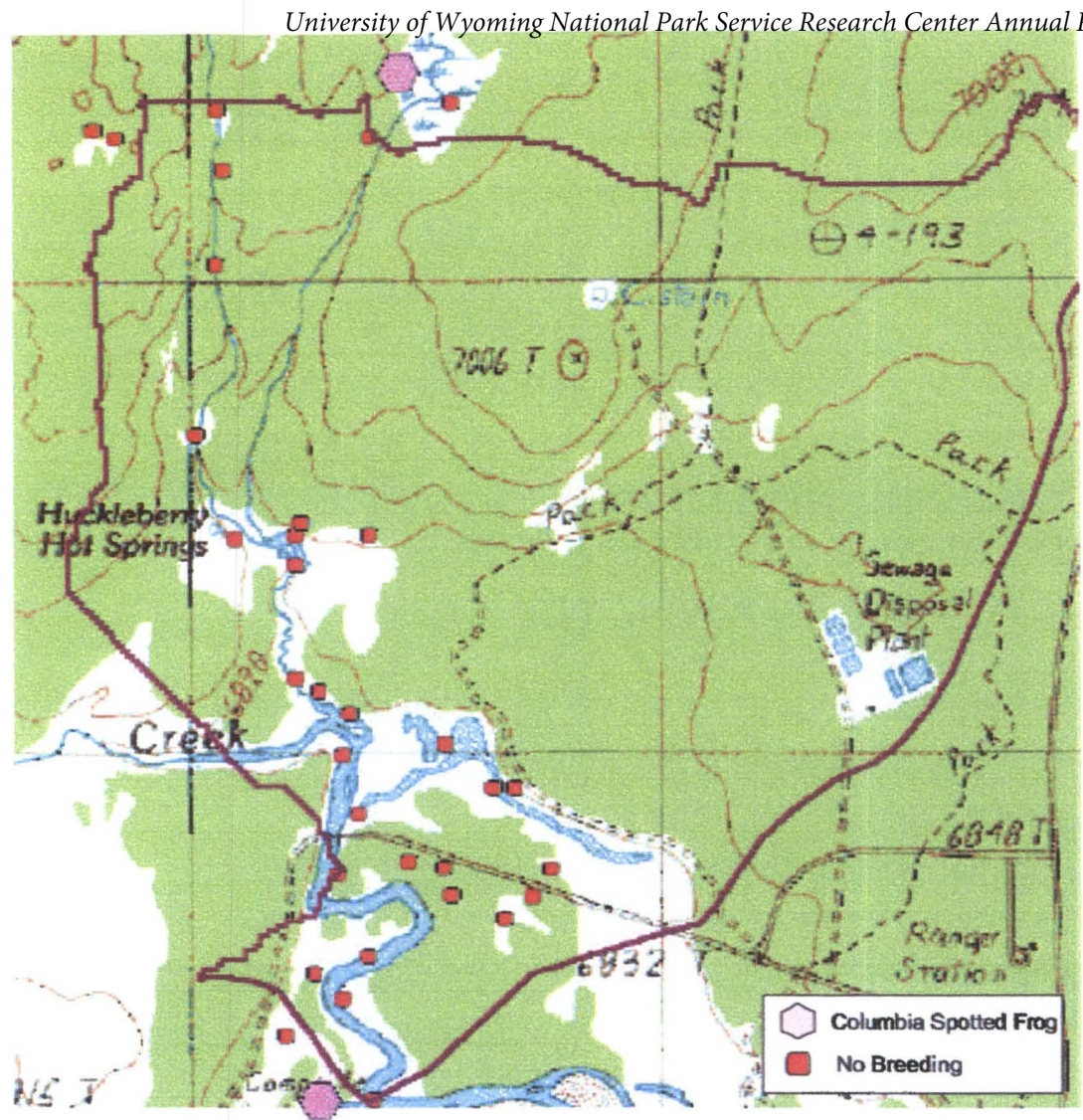

Figure 11. Polecat Creek-Huckleberry Hot Springs watershed unit, JODR. Surprisingly few breeding sites were found given the apparent high quality of wetlands. Some areas were sampled just outside the unit, due to later readjustments of HUC boundaries in GRTE/JODR. These sites were included in the unit site counts and analysis.

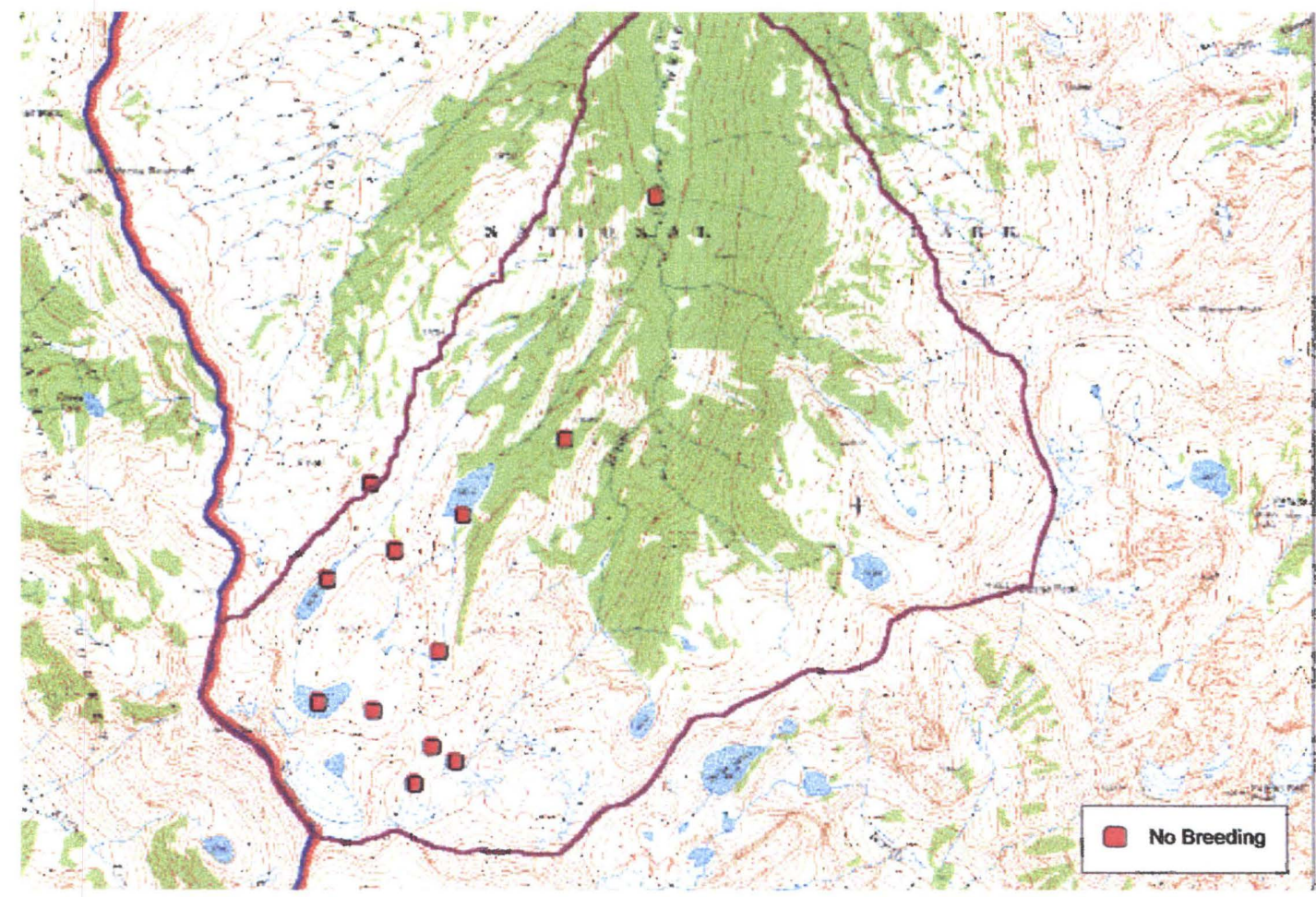

Figure 12. Upper Moose Creek watershed unit, GRTE. No breeding sites and no amphibians were found. This was the highest elevation site surveyed. Amphibians may be limited both by the high elevation and the steep gradient of Moose Creek (Webb Canyon) downstream of the unit. 


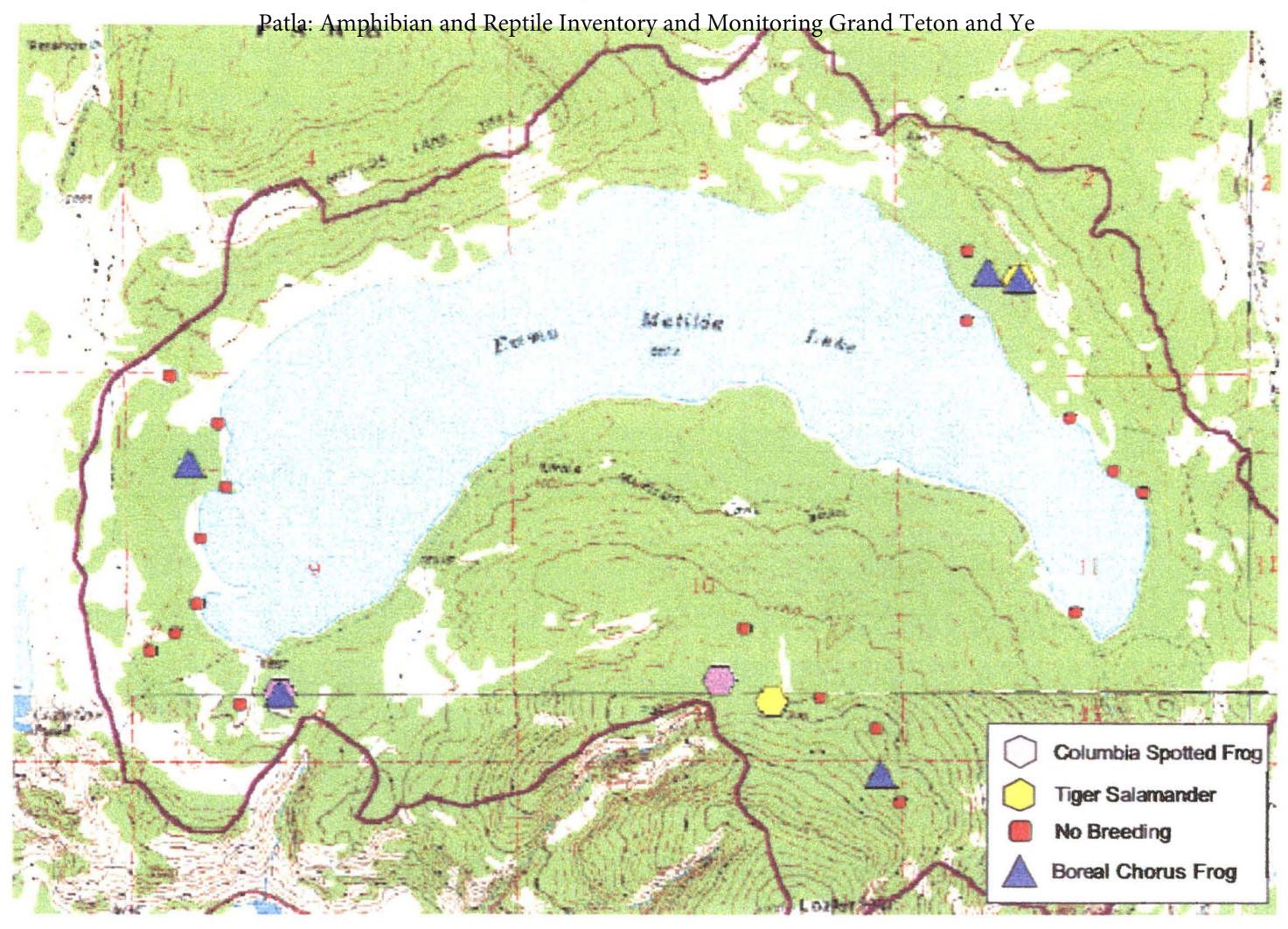

Figure 13. Emma Matilda Lake watershed unit, GRTE. Portions of the lakeshore were surveyed, but no amphibian breeding sites were found, and only one frog was observed. The discrete wetland sites scattered in uplands above the lake and on Lozier Hill provide breeding habitat.

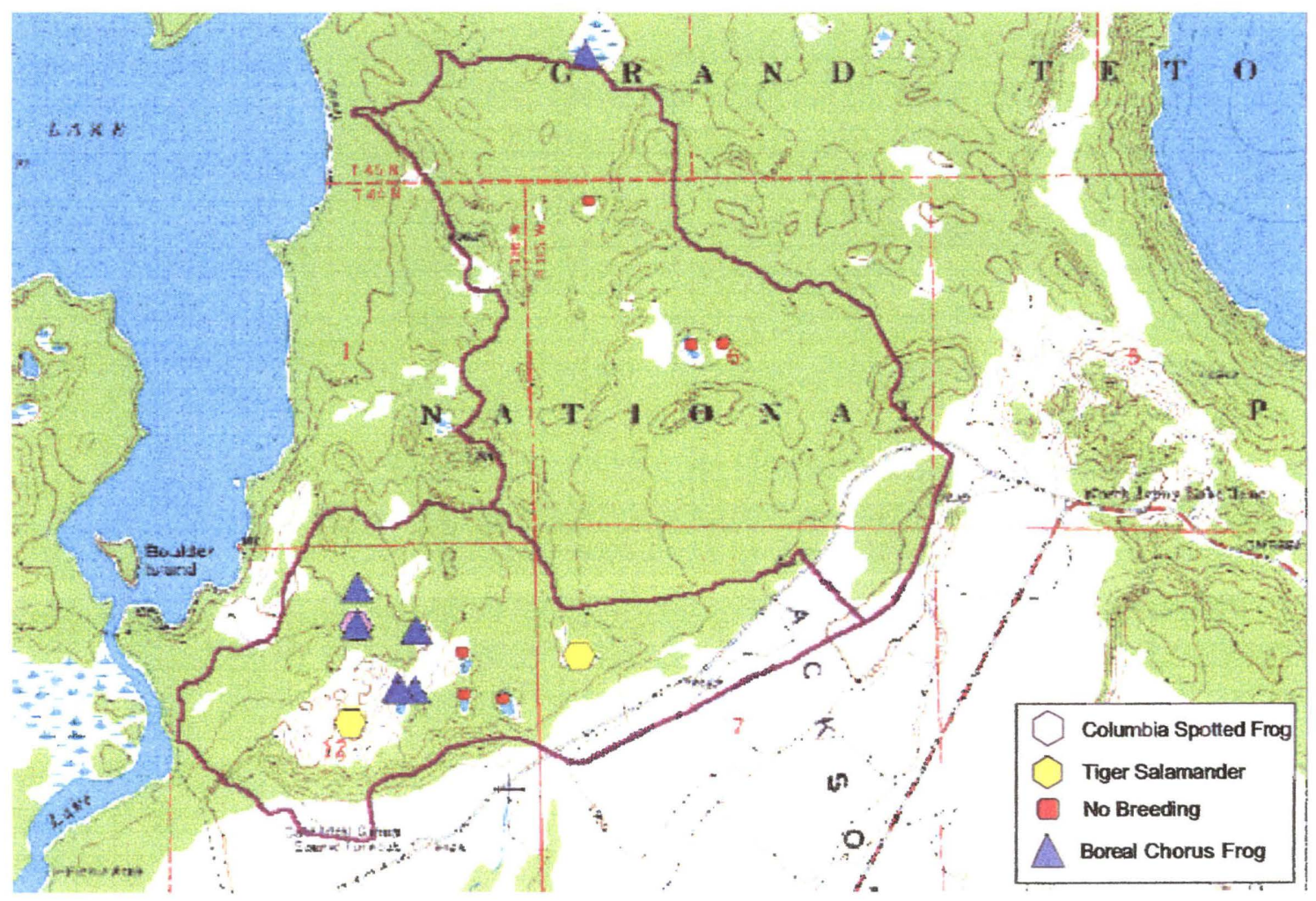

Figure 14. Leigh Lake moraine watershed unit, GRTE. Two watershed units were combined for this survey because the selected unit (on the north) had very few sites. 


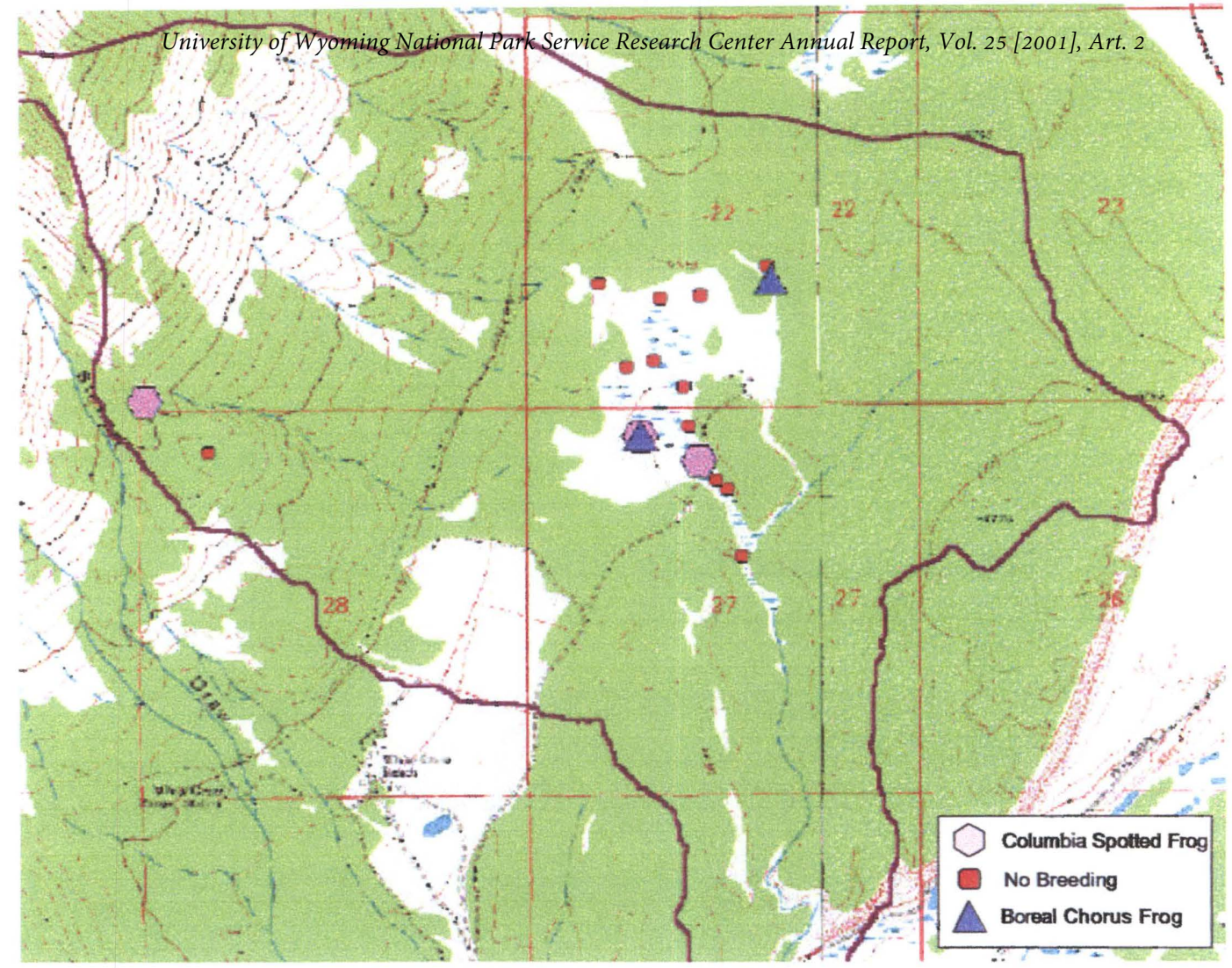

Figure 15. Stewart Draw-Valley watershed unit, GRTE. The large wetland in the center of this unit had a number of old, inactive beaver ponds which may have formerly provided more abundant breeding habitat than is currently available.

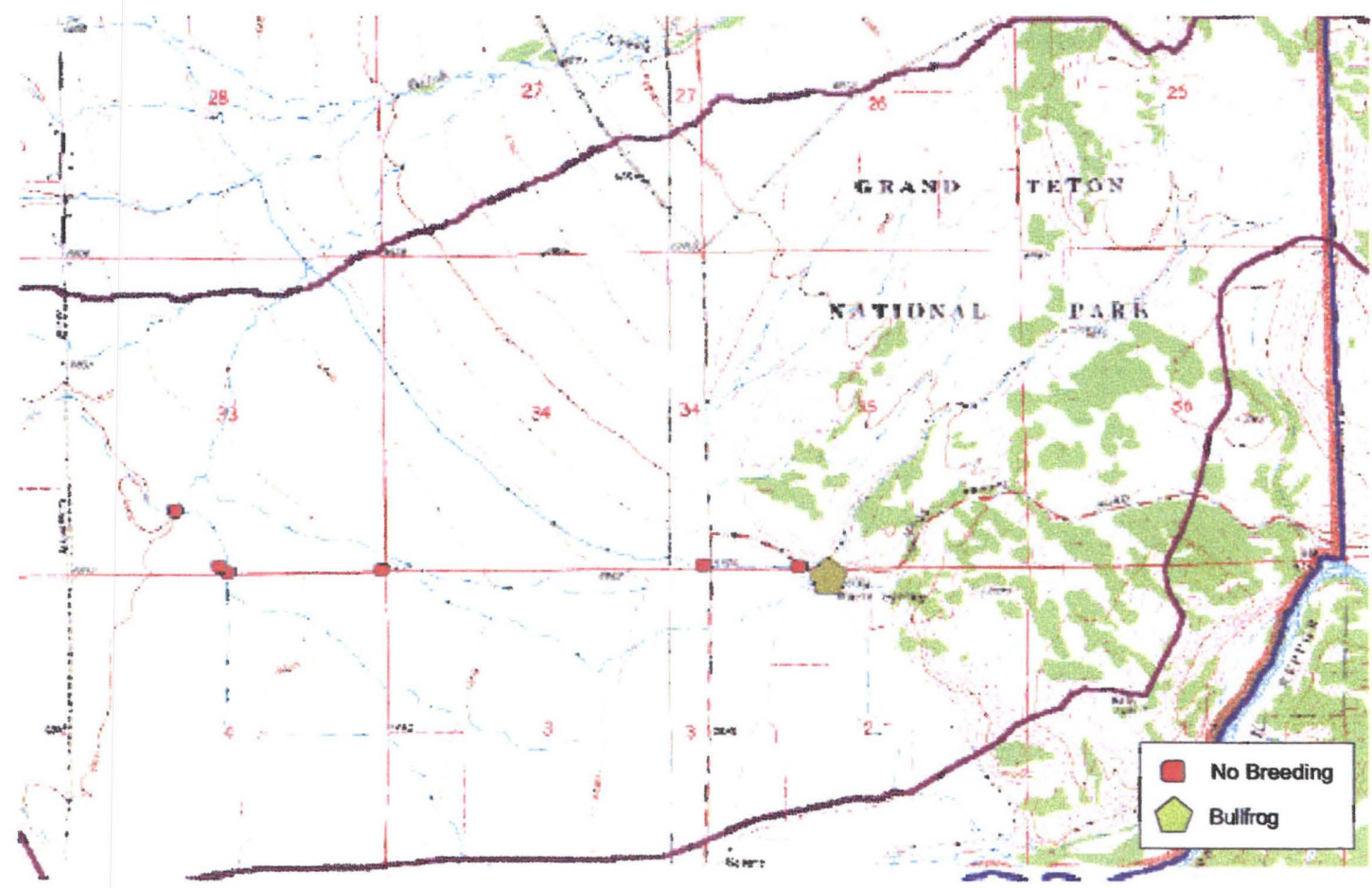

Figure 16. Kelly Wam Springs watershed unit, GRTE. Wetlands with suitable habitat are scarce in this unit but we surveyed along ditches to search for amphibians or unmapped wetlands. No native amphibians were found. Bullfrogs appear to be thriving at Kelly Warm Springs. Their tadpoles disperse along the ditches flowing out of the springs. 


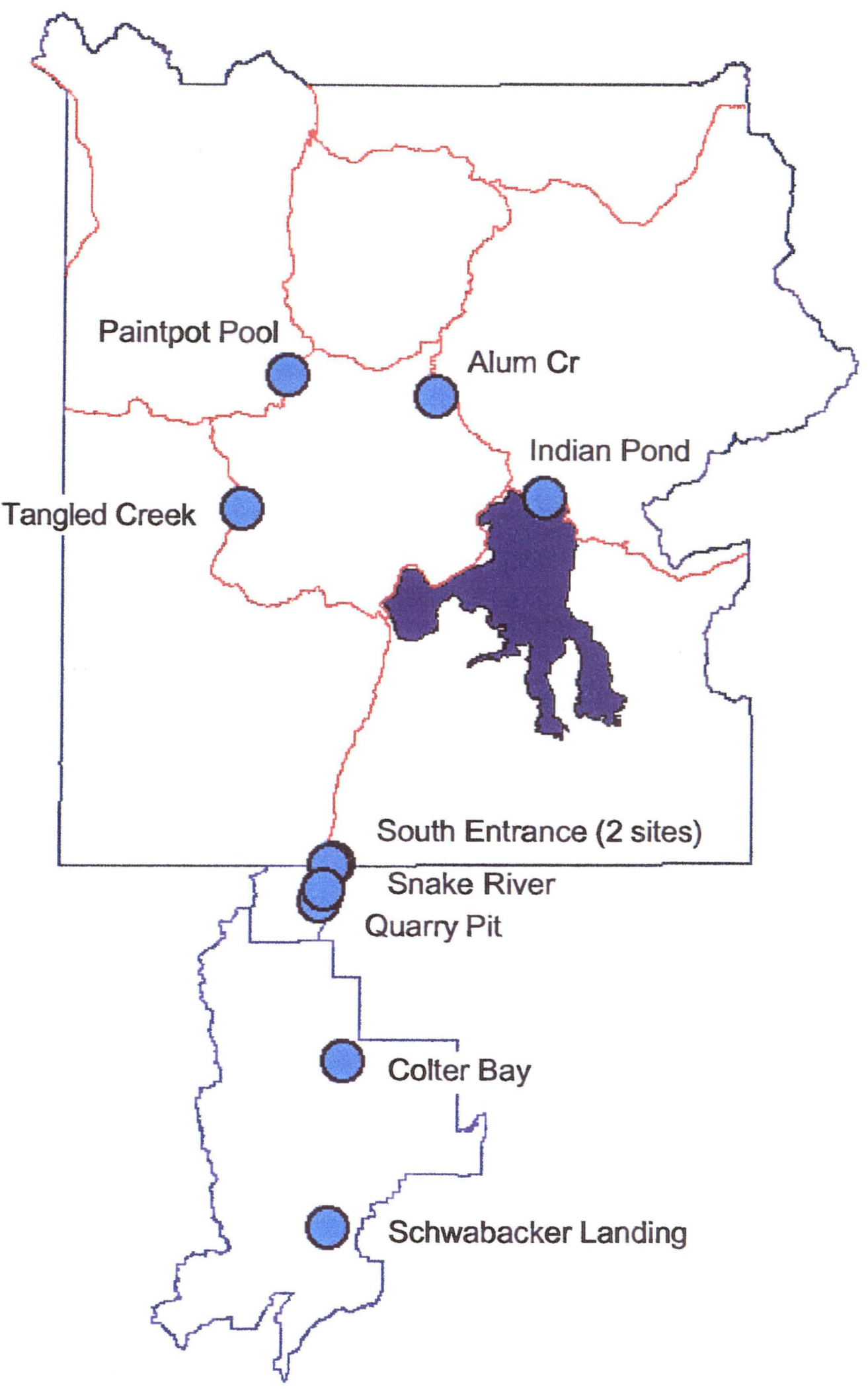

Figure 17. Boreal Toad targeted survey and monitoring sites, 2001. 


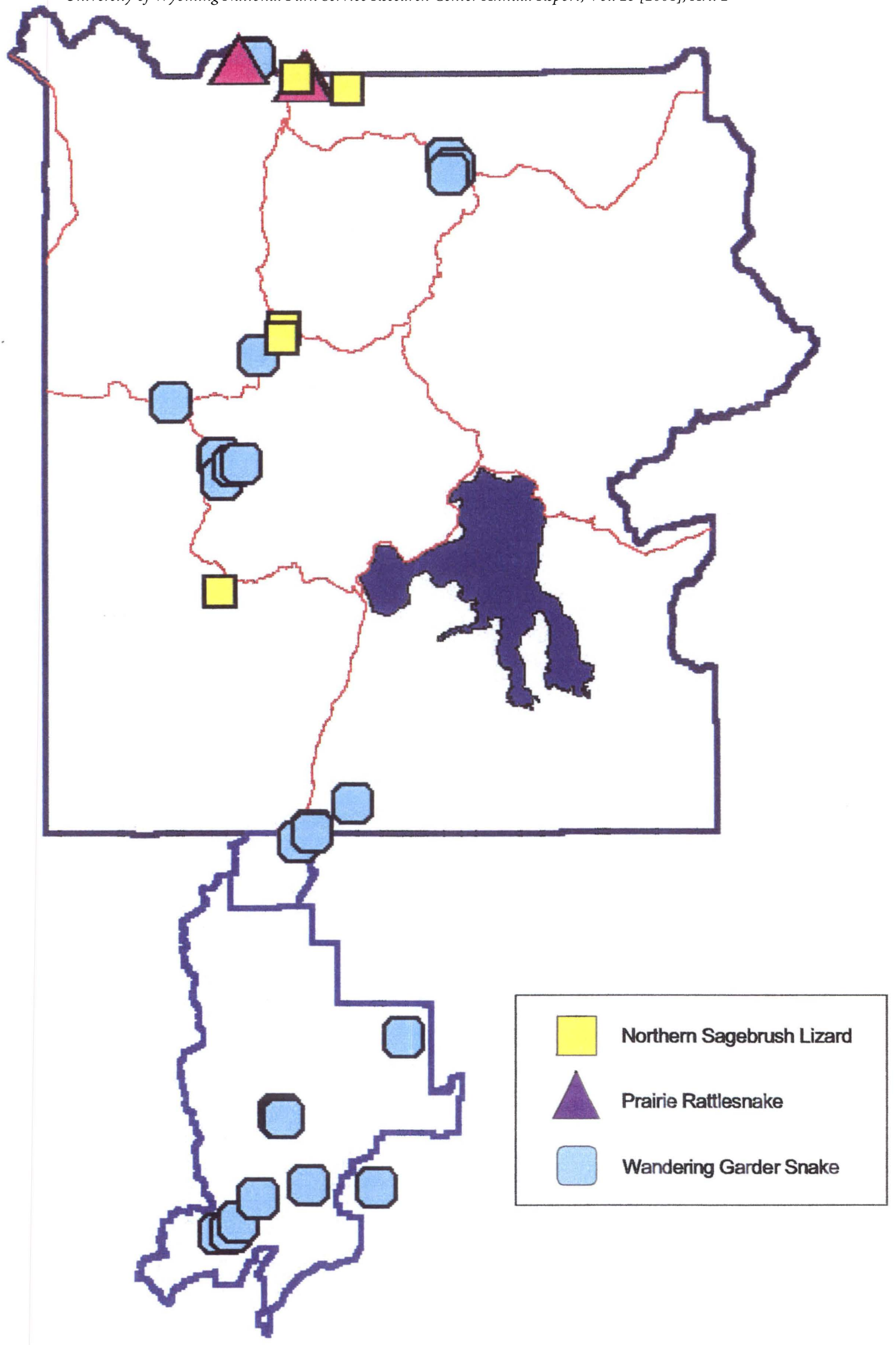

Figure 18. Reptile observations in 2001. 


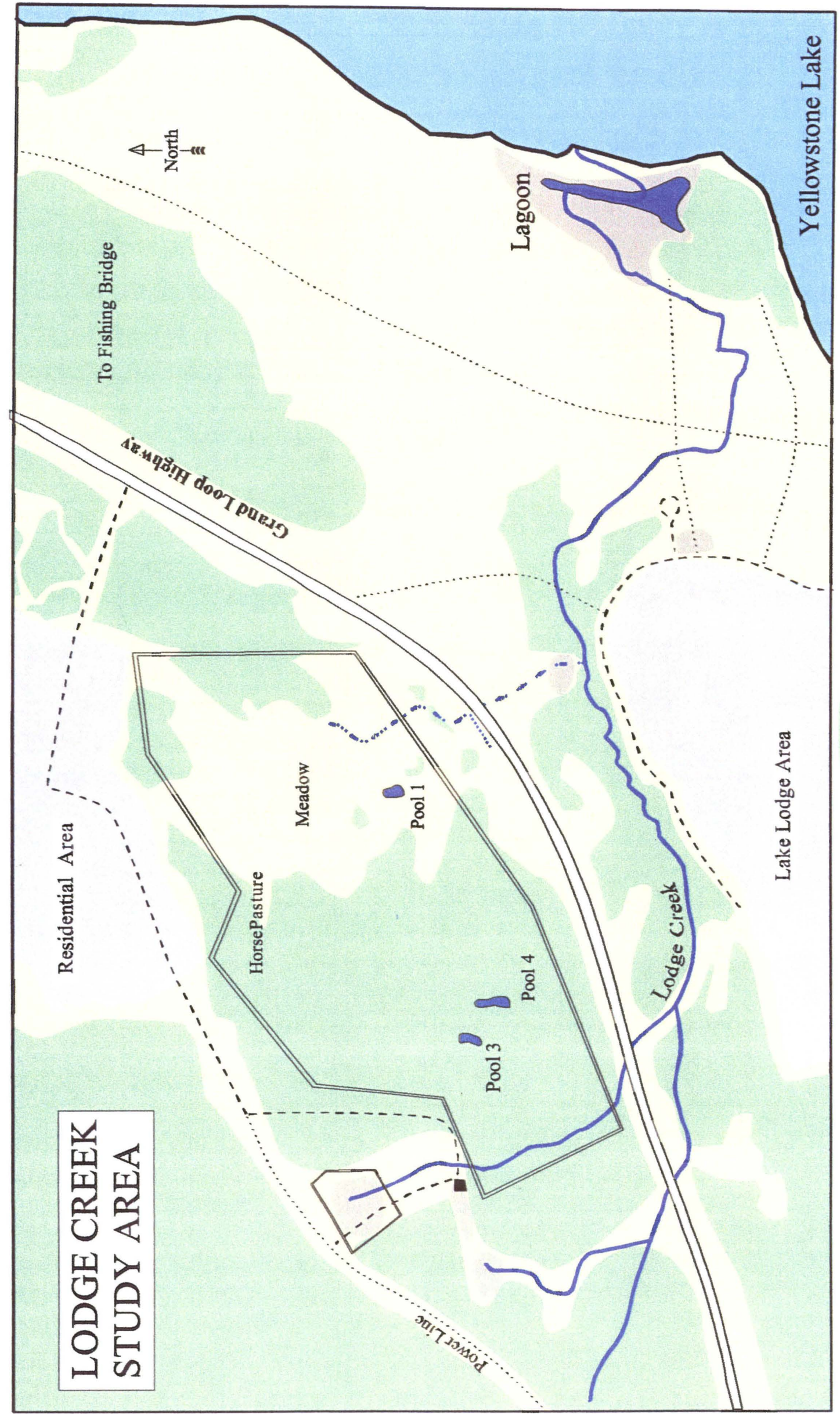

卺

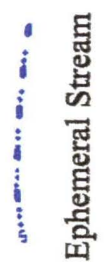

| 焉

- $\overrightarrow{8}$

各

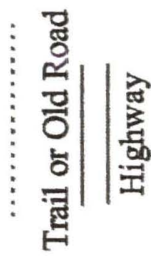



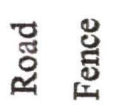

i 


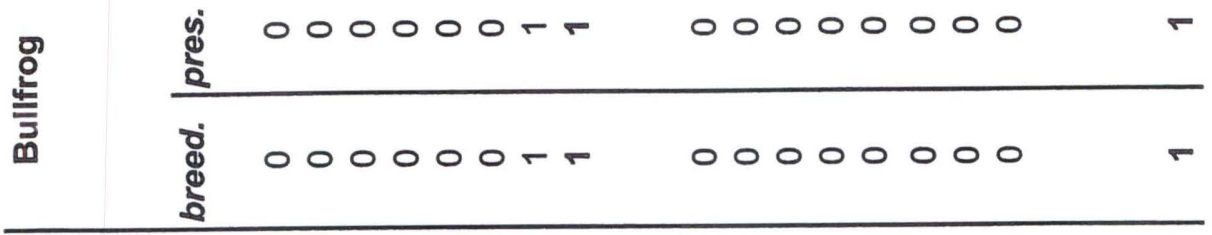

\begin{tabular}{|c|c|c|c|c|c|c|}
\hline $\begin{array}{l}\text { OD } \\
\text { 눈 } \\
\frac{1}{0}\end{array}$ & ఏ్d & nO 0 T & $\underset{\sim}{ }$ & nー+유 & g & เ \\
\hline $\begin{array}{l}\text { 苂 } \\
\text { के }\end{array}$ & 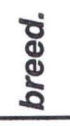 & $N O m-m$ & क & $\nabla 000 \mathrm{~m} 100$ & 요 & g \\
\hline 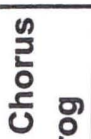 & ฏ் & NOTrO & 8 & $r-a 0-0-N$ & $\stackrel{20}{\leftarrow}$ & $\stackrel{9}{2}$ \\
\hline 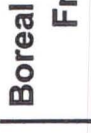 & $\begin{array}{l}\text { ठ் } \\
\text { ప్ }\end{array}$ & o o n N N & $\stackrel{2}{\pi}$ & - เ & g & ஜூ \\
\hline 윰 & ఏ్ & No000 & N & $0-000000$ & $r$ & m \\
\hline ๕ัँ & $\begin{array}{l}\text { वें } \\
\Phi \\
5\end{array}$ & 00000 & 0 & O-OONOOO & $m$ & m \\
\hline
\end{tabular}

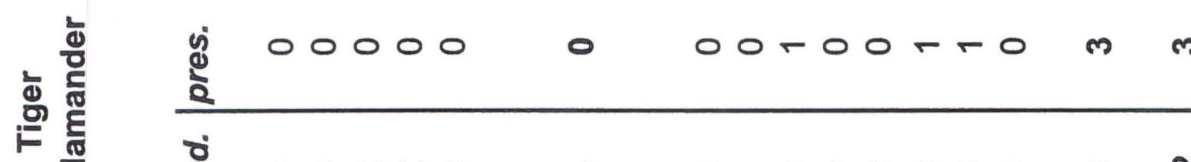

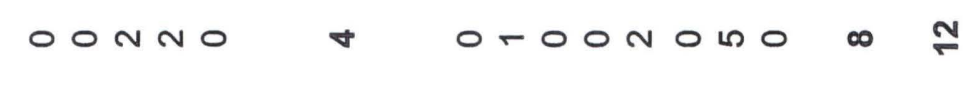

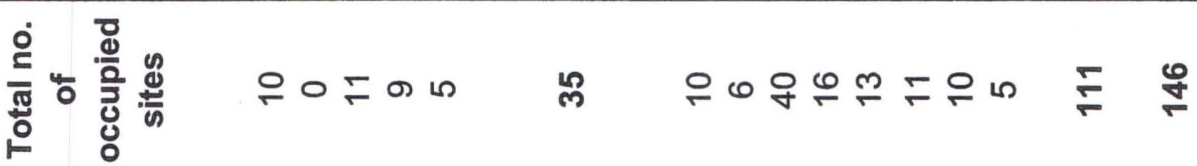

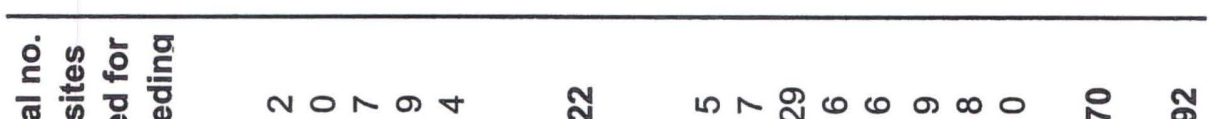

ल

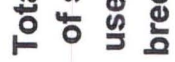

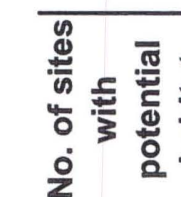

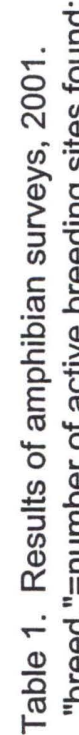

กัササ \&

पै क ष

之ं क

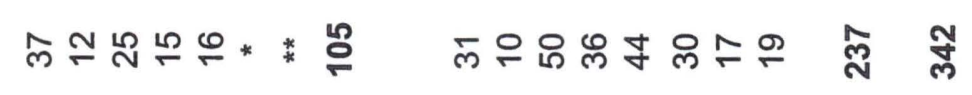

ํํㄹ

N

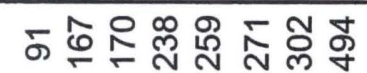

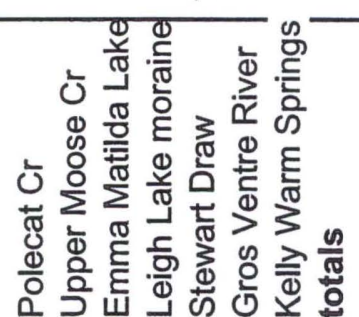

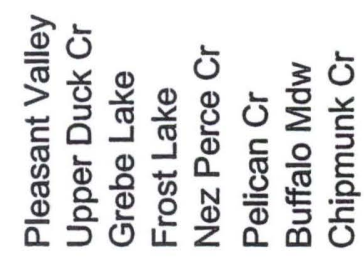

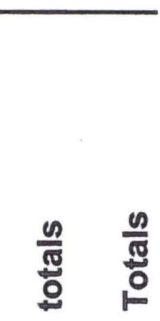

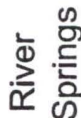

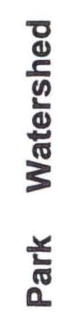

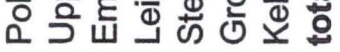

들 융

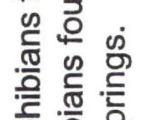

을

तั 을 ह 든

은

बं

은 迆

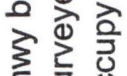

क क

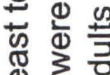

(1) त

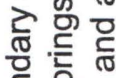

डิ की थ

है

西 3

든 홍을

웅

¿

ฟั

के

하엔

कि $\frac{1}{0} .5$

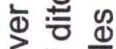

는

क

屯

ह

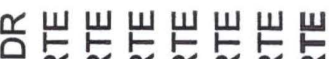

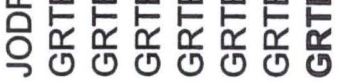

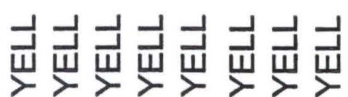

声言 


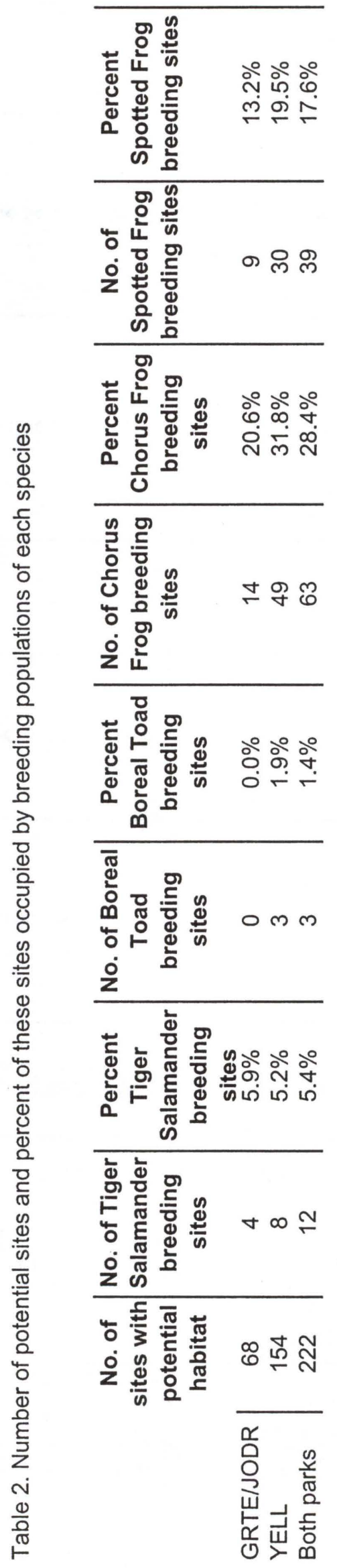




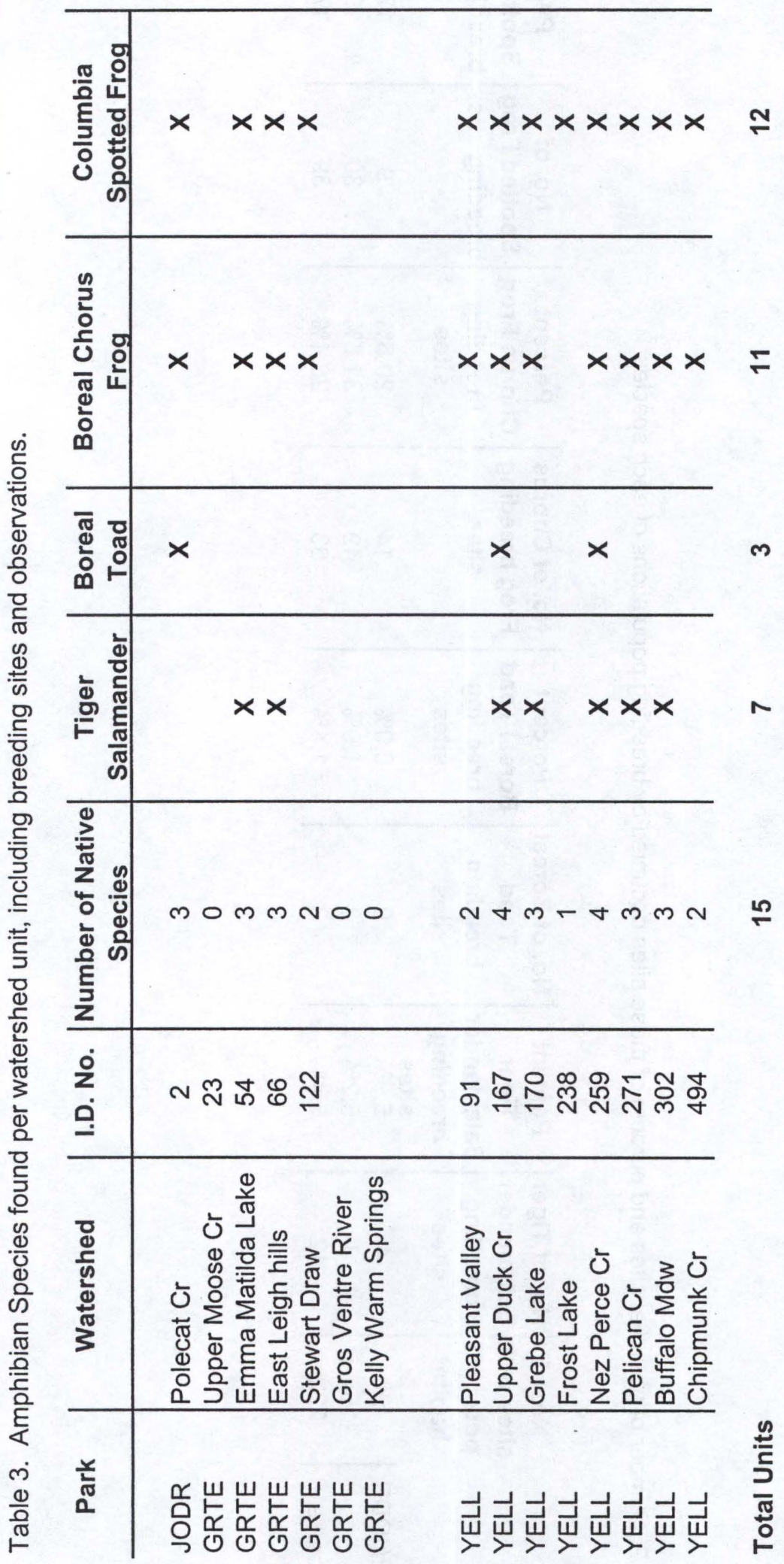



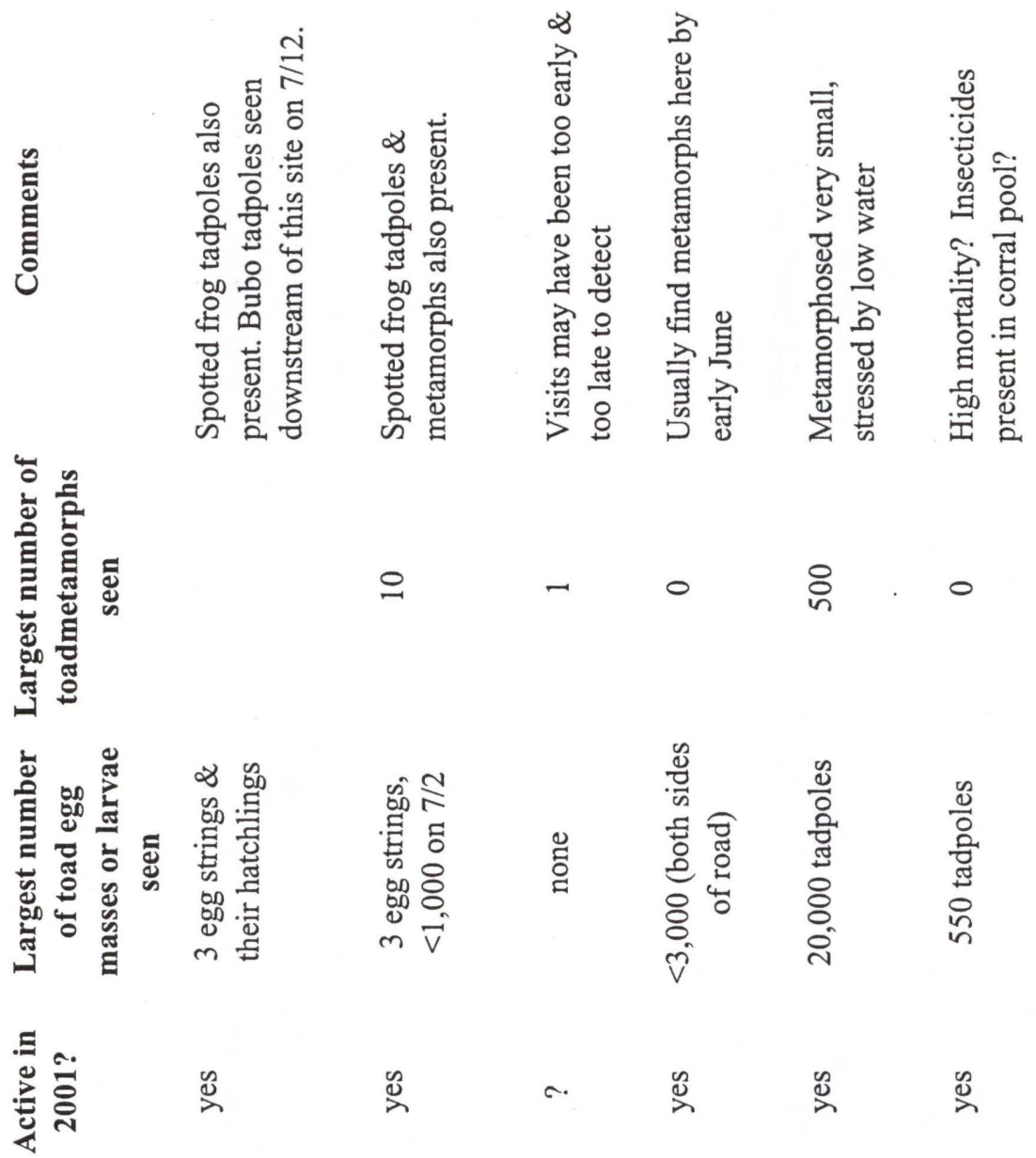

$\stackrel{\infty}{\infty} \quad$ a. $\stackrel{\infty}{\infty} \quad \stackrel{\infty}{\infty}$

홍

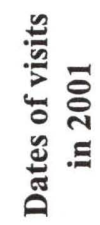

$\frac{0}{n}$

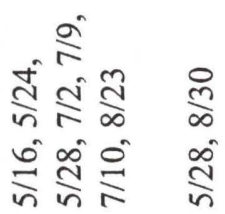

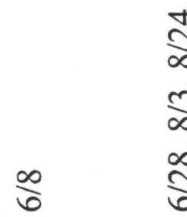

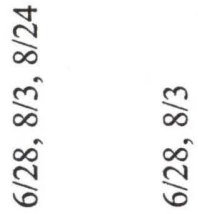

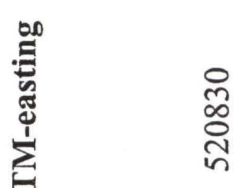

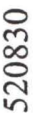

$\underset{n}{n}$

๗ু

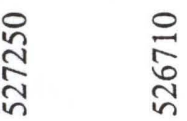

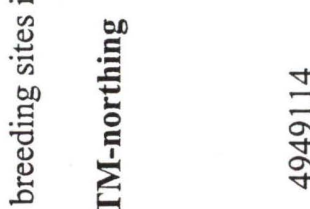

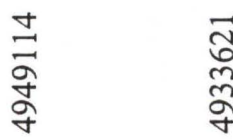

तु
๙ু
q

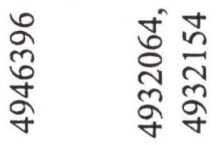

8
ㅇํㅇ
$\infty$
+

8
$\stackrel{0}{0}$
$\infty$
$\infty$
+

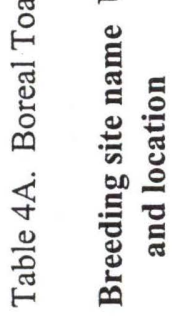

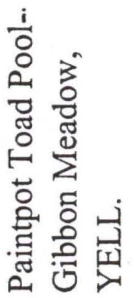

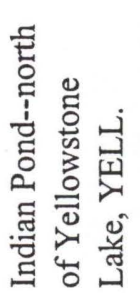

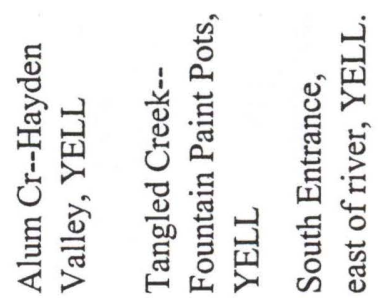

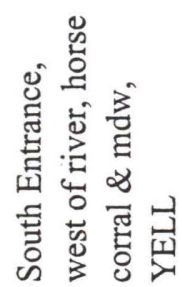



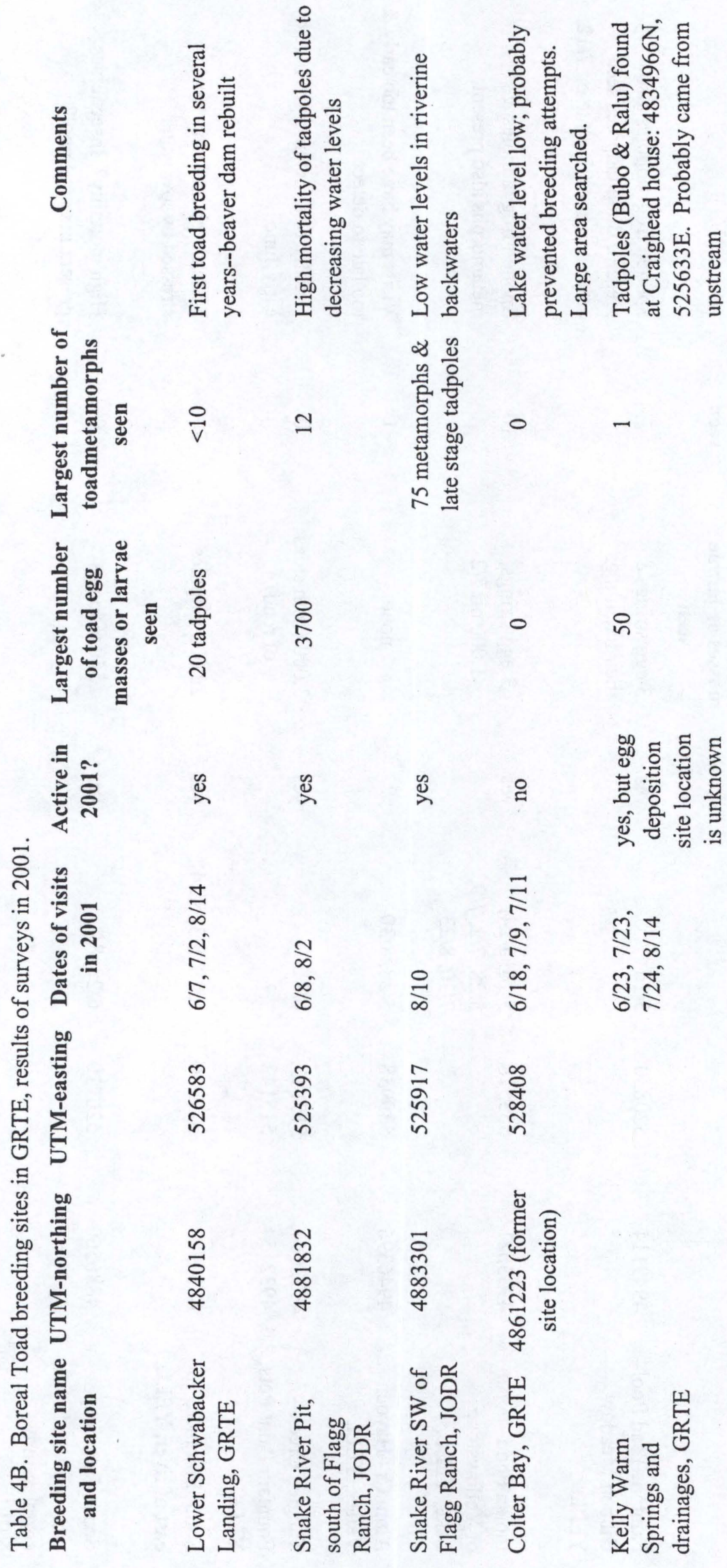
Table 5. Results of monitoring Columbia Spotted Frogs at the Lodge Creek sentinel site.

\begin{tabular}{|c|c|c|}
\hline & & \\
\hline $\begin{array}{l}\text { Number of egg masses } \\
\text { Pool } 3 \text { (main study area) }\end{array}$ & 14 & 7 \\
\hline FHA meadow & (unknown) & 6 \\
\hline Lagoon & $35-40$ & 30 \\
\hline \multicolumn{3}{|l|}{ Date of egg deposition } \\
\hline Pool 3 & $5 / 15-5 / 27$ & $5 / 15-5 / 21$ \\
\hline FHA meadow & (unknown) & mid May \\
\hline Lagoon & $5 / 15-5 / 19$ & about May 21 \\
\hline \multicolumn{3}{|l|}{ Pools dry? } \\
\hline Pool 1 & About $7 / 12$ (est) & Вy $7 / 9 / 01$ \\
\hline Pool 4 & By about $8 / 20$ & By $8 / 3 / 01$ \\
\hline Pool 3 & About 8/10 & By about $8 / 20 / 02$ \\
\hline FHA meadow & (unknown) & By $8 / 3 / 01$ \\
\hline Lagoon & Persists & Persists \\
\hline \multicolumn{3}{|l|}{ Metamorphosis? } \\
\hline Pool 3 & Probably none & Scant. Max number seen: 10 . Mean SUL: $14.3 \mathrm{~mm}(\mathrm{se}=.009)$ \\
\hline FHA meadow & ? & None. \\
\hline Lagoon & $\begin{array}{l}\text { Some. }<30 \text { found on } \\
8 / 28\end{array}$ & $\begin{array}{l}\text { Good. Max number seen: } 33 \text {, and seen consistently on } 4 \\
\text { visits, } 8 / 9 \text { to } 9 / 14 / 01 \text {. Mean } S U L=27.8 \text { ( } \mathrm{se}=.009 \text { ) }\end{array}$ \\
\hline
\end{tabular}

\section{Capture Results}

2000

Number Caught

Percent juv/female/male

Mean SUL $(\mathrm{mm})$

SUL, SE

Min. SUL

Max SUL

\section{1}

Number Caught

Percent juv/female/male

Mean SUL (mm)

SUL, SE

Min. SUL

Max SUL

Mean Wt (g)

Weight, SE

Min Wt

Max WT

Ratio Weight/Length, mean

Ratio Weight/Length, SE

$\begin{array}{ccc}\begin{array}{c}\text { First Capture } \\ \text { 146 total }\end{array} & & \\ \text { Juvenile } & \text { Females } & \text { Males } \\ 73 & 32 & 41 \\ 50 \% & 22 \% & 28 \% \\ 37.9 & 56.5 & 51.3 \\ 0.45 & 1.46 & 0.44 \\ 29.6 & 46.1 & 42.2 \\ 46.4 & 78.2 & 56.0\end{array}$

$\begin{array}{ccc}\begin{array}{c}\text { Second Capture (8/23-8/25/00) } \\ \text { 129 total } \\ \text { Juv }\end{array} & \begin{array}{c}\text { Females } \\ \text { Males }\end{array} \\ 67 & 26 & 36 \\ 52 \% & 20 \% & 28 \% \\ 39.2 & 59.2 & 53.9 \\ 0.40 & 1.65 & 0.59 \\ 32.6 & 49.1 & 46.2 \\ 46.1 & 74.9 & 61.8\end{array}$

